\title{
ASSESSMENT OF LAND SUITABILITY AND WATER RESOURCES FOR DIFFERENT CROPS IN KHARGA - NEW VALLEY -EGYPT.
}

\author{
Ahmed Sayed $^{1}$; Abd Elslam Elwa ${ }^{2}$ and Y.A. Abd El-Hady ${ }^{3}$ \\ 1-Desert Research Center, Department of Pedology, El-Matariya, Cairo 11753, Egypt \\ 2-Soil Physics and Chemistry Department, , Desert Research Center, El-Matariya \\ 11753, Cairo, Egypt \\ 3 - Department of Hydrogeochemistry, Desert Research Center, El-Matariya, Cairo, \\ 11753, Egypt
}

"Corresponding author - Tel: +2 01025109331;

${ }^{2}$ E-mail - abdelsalamelwa33@yahoo.com

Key Words : Agricultural soil suitability, land capability, heavy metals accumulation, Translocation (TF) and Biological accumulation coefficient

\section{ABSTRACT}

Kharga Oases is located in the western desert of Egypt. El-Monera, Al-shirka, Kharga, Nasser Al-thawra, Jinnah, East Bulaq were selected as case studies. The purpose of current research is to assess the land capability and the suitability of annual, semi-annual and perennial crops for agriculture. In addition, evaluate the contamination by heavy metals of the soil, the crops and the irrigation water. The obtained data indicate that the main land geomorphic units were Pedilpain, Sand sheets, and Playa. According to two land evaluation systems applied for evaluating the studied soils; Sys and Verhey and Land evaluation decision support system (MicroLEIS-DSS). The results indicated that Kharga Oases soils belong to class marginally suitable (S3) and currently not suitable (N1). While land capability classes using the CERVATANA model are marginally suitable (S3 I). The area under investigation has been divided into two relative suitability classes; suitable ( $\mathrm{S} 2$ class) and marginally suitable (S3 class). The main limitations were useful depth, texture, drainage, salinity, carbonate, and sodium saturation. Correcting those factors will improve the land capability and suitability for productivity. The accumulation of heavy metals, such as $\mathrm{Cr}, \mathrm{Cu}, \mathrm{Zn}, \mathrm{Ni}, \mathrm{Pb}$, and $\mathrm{Cd}$, in soils, irrigation water, and commonly grown crop plants (wheat, faba bean, and quinoa), was studied in fields that represented major geomorphological units. Irrigation water at various locations was slightly saline, with no sodium hazard. Deep-water wells in New Valley, there is an increase of the two elements of iron and manganese, and take into account when using modern irrigation systems. The findings also revealed that heavy metal levels in irrigation water were within the acceptable range. The total content of $\mathrm{Cr}, \mathrm{Cu}, \mathrm{Zn}, \mathrm{Ni}, \mathrm{Pb}$, and $\mathrm{Cd}$ in top soil samples was higher than in subsoil samples, indicating an anthropogenic source of contamination. The main total and extractable 
heavy metals, on the other hand, showed low contamination levels in the soil and within international limits except total $\mathrm{Cd}$ metal in Bulaq village in the surface layer $(0-30 \mathrm{~cm}) 5.3 \mathrm{mg} / \mathrm{kg}$. All the total heavy metals in the plants in the studied soils within international limits except $\mathrm{Ni}$ and $\mathrm{Cd}$ metals in some layers. Translocation factor (TF) and biological accumulation coefficient (BAC) of all elements in the studied soils were determined. they are $\mathrm{TF}$ and BAC are higher in in roots, stalk and leaves than some fruits ,But other can accumulate some heavy metals by higher degree and can reached to the food chain directly or in directly.

\section{INTRODUCTION}

The western desert accounts for almost two-thirds of the total surface area of Egypt. It represents a large potential for agricultural expansion Parks, (2016). The New Valley Governorate is located in southwestern Egypt, and shares international boundaries with Libya and Sudan. The internal borders of the Governorate are with the governorates of Minya, Gizeh and Matruh in the North, and the governorates of Assiut, Sohag, Qena, Luxor and Aswan in the East. According to (Ezzelarab, et al., 2021) Kharga Oasis is an approximately $200 \mathrm{~km}$ long depression in the north-south direction and $20-80 \mathrm{~km}$ wide in the east-west direction. The New Valley Government is an important sector for agricultural development. The New Valley is the largest governorate in Egypt, it occupies the southern half of the western desert of Egypt, covering an area of $458,000 \mathrm{Km}^{2}$, or about 48 $\%$ of the total surface area of Egypt. The location of the El-Kharga depression is full of marine sediments covered with sandy layers (Gameh, et al. 2017)

A shortage of irrigation water, excessive levels of salts in irrigation water and soil, poor agricultural drainage, and sand creeping are all obstacles to the Governorate's agricultural growth. In addition, illogical water and soil management, such as dependency on surface irrigation, haphazard well drilling, farmers' lack of expertise in dealing with soil degradation concerns, and ultimately, insufficient agricultural extension services, exacerbate the Governorate's agricultural situation (Gad et al., 2016, Gameh, et al. 2017 and Soliman, 2020).

According to (Karlen, \& Stott, 1994, Sayed, 2013 and Tezcan, et al., 2020) land evaluations are important for the development of sustainable agriculture. Based on the value of several soils and environmental indicators, the methodology for the assessment of agricultural land is applied to the mapping units to calculate the suitability index. Actual and potential land suitability and crop requirements calculated by using the ALES was used by (Kawy, \& Abou El-Magd 2013). The selections of the most promising crops to be evaluated according to their suitability for the investigated area 
were based on the following parameters: sustaining the natural resources, national strategic plans and economic viability. Based on most suitable traditional crops are proposed for the studied area. The main selected crops are clover, wheat, beans, and sugar beet, onion, maize, sunflower, tomato, potato, groundnut, pea, barley, sesame, and carrot. Land capability classification of Al-Kharga Oases using remote sensing and GIS studied by (Gad, 2013). The obtained data indicate that the highly capable soils represent $24.5 \%$ of Al-Kharga Oases, these soils are associated with the Typic Haplotorrerts and Typic Torrifluvents sub-great groups. The moderately capable soils represent $1.5 \%$ of the total area of Al Kharga Oases. They were found to be associated with sub- great group soil Typic Torriorthents. The low capable soils represent $36.0 \%$, this class is associated with the soils of Torripsamments great group. Rock land and non-capable soils representing $38.0 \%$ of Al-Kharga Oases. Gameh, et al., (2017) studied Assiut University Farm in El-Kharga Oasis, New Valley Governorate, the goal of this research was to assess the capability and suitability of the new area before cultivation and the old farmed area, as well as to look into the impact of cultivation on the physical and chemical features of the soils under investigation. Land Capability for irrigation of the new area was found to be $30 \%$ marginally suitable, $43 \%$ currently not suitable, and $26 \%$ permanently not suitable, whereas for the old cultivated area, it was found to be $11 \%$ moderately suitable, $27 \%$ marginally suitable, $27 \%$ currently not suitable, and $33 \%$ permanently not suitable. In El-Kharga, the soil texture classes range from sandy loam, silty loam, clay loam, and loam to clay with a finer texture. The majority of these samples are moderate to highly strong saline, with little organic content and significant calcium carbonate. In most locations, soil reaction $(\mathrm{pH})$ is slightly to moderately alkaline. Gypsum content ranges from low to moderate, with ElKharga having the lowest. The cation exchange capacity (CEC) values of various soils are positively related to the fine particle content. On the basis of the land capability classification, most of the soils surveyed are classified in classes (II and III). Most of these soils have high salinity and sodium limits (Ghallab, et al. 2005). Heavy metal pollution of the soil is a major environmental hazard (Goyer, 1997). The environment in which plants grow and their growth medium (soil) from which heavy metals are taken up by plant roots or foliage are the sources of heavy metals in plan0ts (Okoronkwo et al., 2005). Heavy metal accumulation in soils is of concern in agricultural production due to the adverse effects on food quality, crop growth and environmental health. (Ma et al., 1994). 
Soil pollution is caused by misuse of the soil, such as poor agricultural practices, disposal of industrial and urban wastes, etc. Soil is also polluted through the application of chemical fertilizers (like phosphate and $\mathrm{Zn}$ fertilizers), and herbicides (Demırezen, \& Aksoy, 2004). Alloway, (2009) reported that crop plants have different abilities to absorb and accumulate heavy metals in their body parts and that there is a broad difference in metal uptake and translocation between plant species and even between cultivars of the same plant species

The study's major goal is to provide some information regarding morphological, physical, and chemical features in order to define the soil assessment units of these soils, with a focus on their agricultural suitability. In addition, assessment of heavy metals contamination of soil, crops and water used for irrigation

\section{Description of the study area}

The governor's capital is the Kharga Oasis, which covers $68223 \mathrm{~km}^{2}$ and accounts for $15.5 \%$ of the governor's total area (Figure 1). It is elongated depression $185 \mathrm{~km}$ long from North to South and approximately $80 \mathrm{~km}$ wide. The Oasis is inhabited by 93,753 individuals representing about $37.59 \%$ of the governor's population. El-Monera, Al-Shirka, Nasser AlThawra, Jinnah, East Bulaq, Bulaq, Sana'a, and Palestine are the eight administrative village units of Kharga. According to (Abou-Korin, 2002 and Abdelhafez, et al., 2021) the major source of water in the New Valley is subterranean water. In 1965, all water wells were self-flowing at high pressures, day and night. Despite higher operating expenses, the government has now installed a pump on virtually every well in the region to provide water.

The climate in Kharga Oasis is typically arid that is characterized by relatively high temperature with almost no rainfall. The maximum mean temperature occurs in the summer, reaching $31.4{ }^{\circ} \mathrm{C}$ in July, while the minimum mean temperature occurs in the winter, reaching $12.55^{\circ} \mathrm{C}$ in January. Annually, the maximum temperature is $30.95{ }^{\circ} \mathrm{C}$ and the minimum temperature is $15.7^{\circ} \mathrm{C}$. Average wind speed is maximum in June $(3.98 \mathrm{~m} / \mathrm{s})$, and minimum in January $(2.69 \mathrm{~m} / \mathrm{s})$, with average value annually of 3.32 $\mathrm{m} / \mathrm{s}$, mostly from the North. The relative humidity is maximum during December and January (45.43-44.44\%), and minimum in May and June (17.36-17.86\%) with annual value of $28.2 \%$ (El-Marsafawy, et al.2019 and Ismael, et al., 2020). The geologic sequence is Cretaceous, Tertiary, and Quaternary, with Pre-Cambrian basement rocks forming the foundation. Elevations on the floor of the El Kharga depression range from near 0 mean sea level (msl) to $120 \mathrm{~m}$ above msl. The geologic maps for El kargah depression illustrate that the floor is mostly covered by shales that alternate in places with some sandstone, shale bedrocks covered by playa deposits 
and/or sand sheets. The results of the geographic region groundwater resource analysis within the Western Desert indicate the supply of property and economic groundwater for one hundred years within the New natural depression Oases of: El-Kharga, El-Dakhla, El-Farafra and El-Bahariya (Ministry of Public Works and Water Resources, 1998): The Nubian sandstone aquifer is the only water source for domestic use and irrigation in the Kharga Oasis. Groundwater belongs to freshwater type with salinity contents ranging from 400 to 900 ppm El-Sankary, (2002) and Salman, (2010)

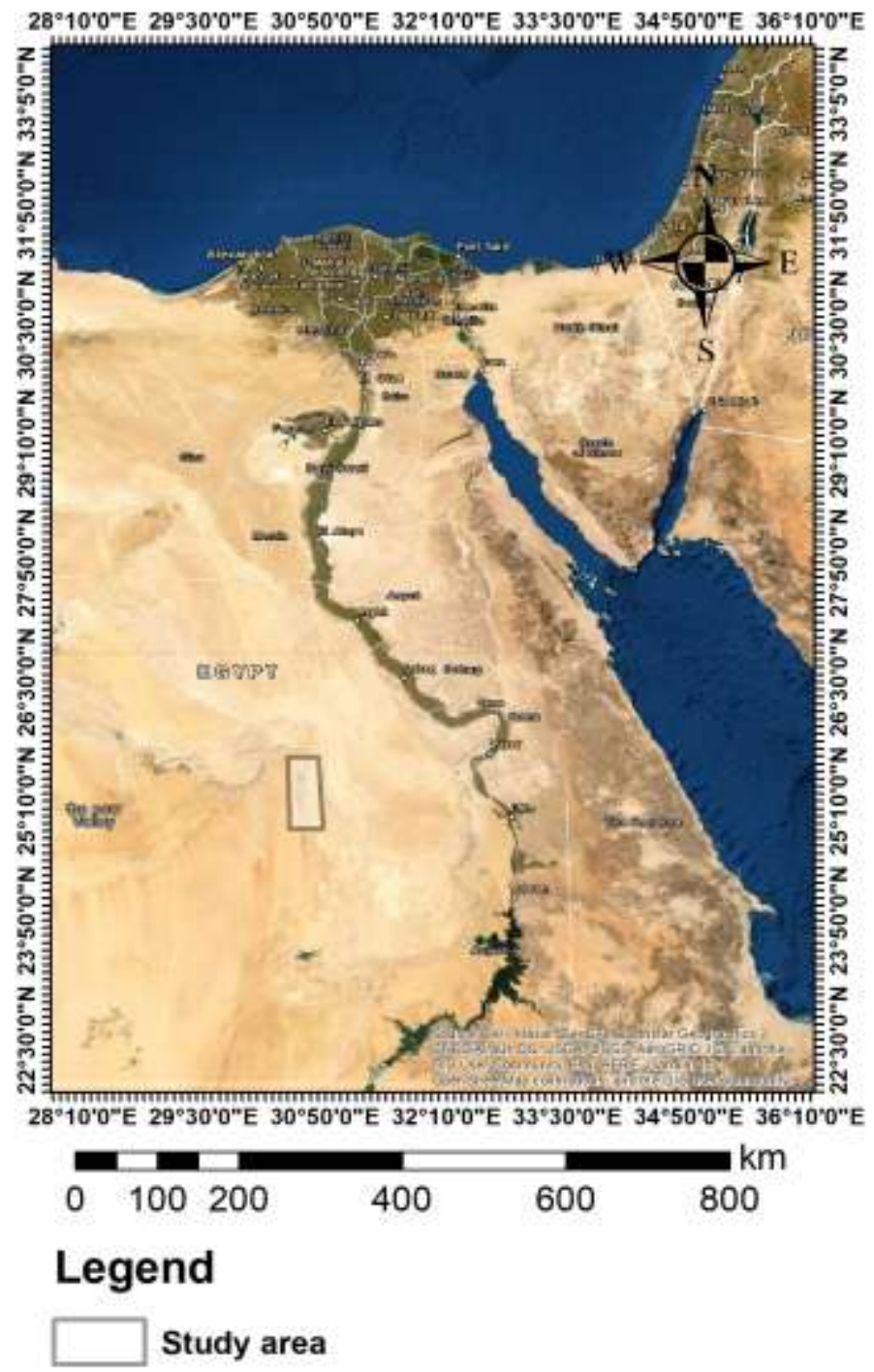

Figure (1): Location of the study area 


\section{MATERIALS AND METHODS \\ Soil, water and plant samples}

Thirteen soil profiles represent the realm beneath study were chosen on the basis of obtainable structural geomorphological mapping units, Fig 2. The obtained geomorphic map showed that, the area comprises distinct geomorphic units namely, pediplain, hills, playa, sabkha, sand dunes, high terraces, wadi deposits, sand sheets and rock land Fig 3. Soil profiles representing the study area were selected using available geomorphological information. These profiles have been dug to a depth of $150 \mathrm{~cm}$, unless they are opposed by a water table or an extremely hard layer. Morphological description of the soil was undertaken according to the criteria established by Field Book for Describing Sampling soils (Schoeneberger, et al., 2002, 2011 and 2012) and FAO (Guidelines for soil description 1990 and 2006). The soil samples collected, represented the resulting morphological variations across the depth of the soil profiles

The collected soil samples were air-dried and passed through a $2 \mathrm{~mm}$ sieve. Gravel content ( $>2 \mathrm{~mm}$ diameter) were determined volumetrically to measure their sizes and percentages from the total sample while the fine soil $(<2 \mathrm{~mm})$ was subjected to physical and chemical analyses as indicated by Black et al., (1982) as follows:

Soil $\mathrm{pH}$, electrical conductivity and soluble cation and anion were determined in the soil extract. Particle size distribution of sandy soils was achieved by dry sieving. The total carbonate content was determined by Collin's calcimeter. The gypsum content was determined using the acetone methodology described by Day, and Black (1982). Exchangeable sodium percentage (ESP) was determined, Day, and Black (1982). The organic matter content was determined by the titration method Walkley and Black (1983). Total trace metals contents in the soil samples and chemically - extractable amounts were determined by the Ionic Coupled Plasma (ICP). Collection of groundwater data in the oases of El Kharga by the Ministry of Irrigation. Data analysis for the assessment of the groundwater for Agricultural irrigation. This assessment includes the analysis for cations: $\mathrm{Na}+, \mathrm{K}^{+}, \mathrm{Ca}^{++}$and $\mathrm{Mg}{ }^{++}$and anions: $\mathrm{Cl}^{-}$, $\mathrm{HCO}_{3}$, and $\mathrm{SO}_{4}{ }^{2}$ and soluble heavy metals and related factors (pH, TDS, and EC) from groundwater samples at El Kharga oases. Plant sampling analysis. The vegetables plant samples were thoroughly washed and air dried, then dried in a dryer at $70^{\circ} \mathrm{C}$ for $4 \mathrm{hrs}$. The dried material was then powdered in a hammer mill sample bottles which were used in plant analysis according to requirements. Digested $0.5 \mathrm{~g}$ from the plant powder by $\mathrm{H}_{2} \mathrm{O}_{2}$ and $\mathrm{H}_{2} \mathrm{SO}_{4}$ was used to determine the plant contents of trace metals under study $(\mathrm{Zn}, \mathrm{Cu}, \mathrm{Ni}$, Co, and $\mathrm{Cr}$ ) by Ionic Coupled Plasma (ICP)., (Nicholson 1984). 


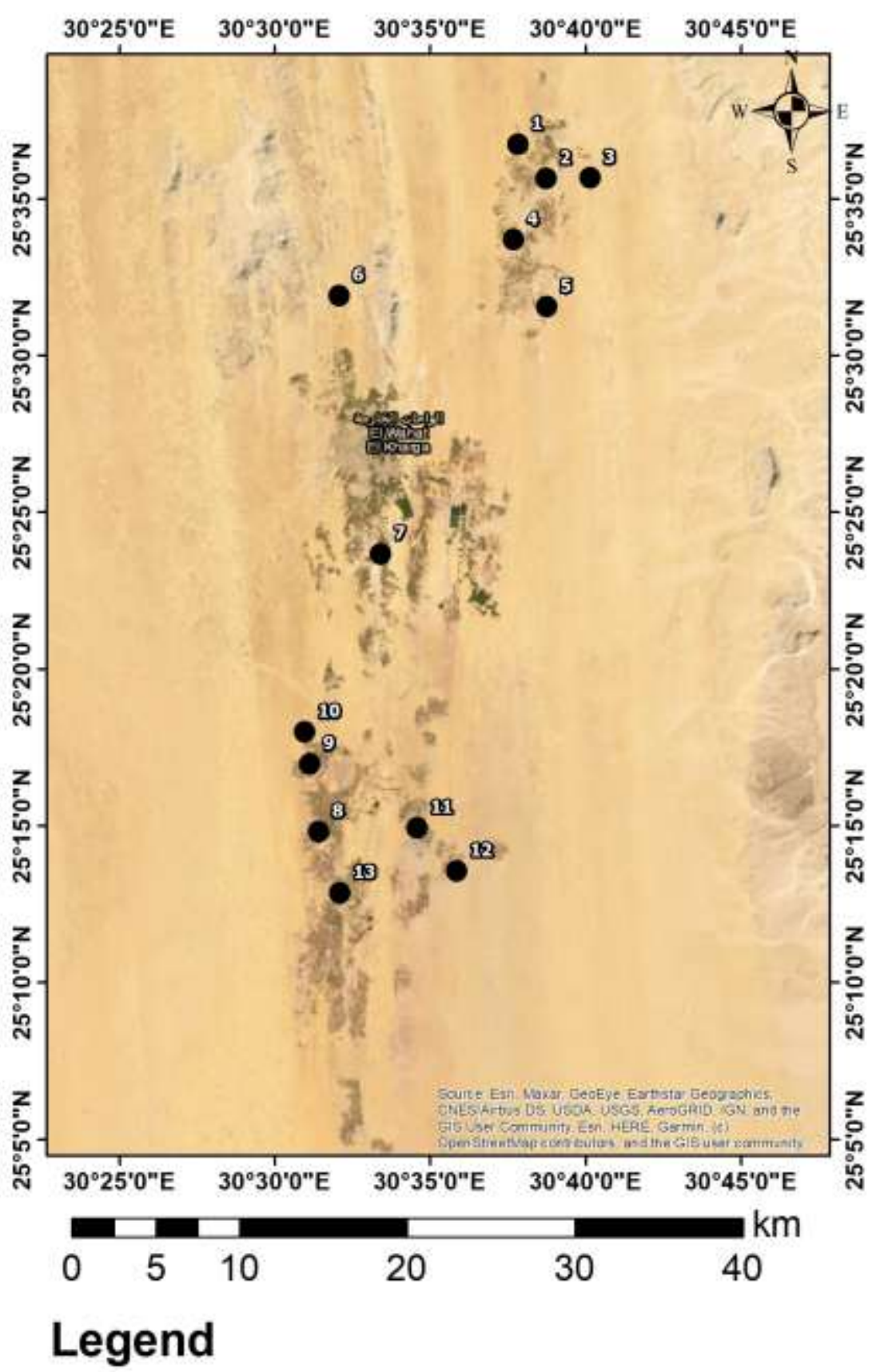

- Soil profiles

Figure (2): Location of soil profile. 


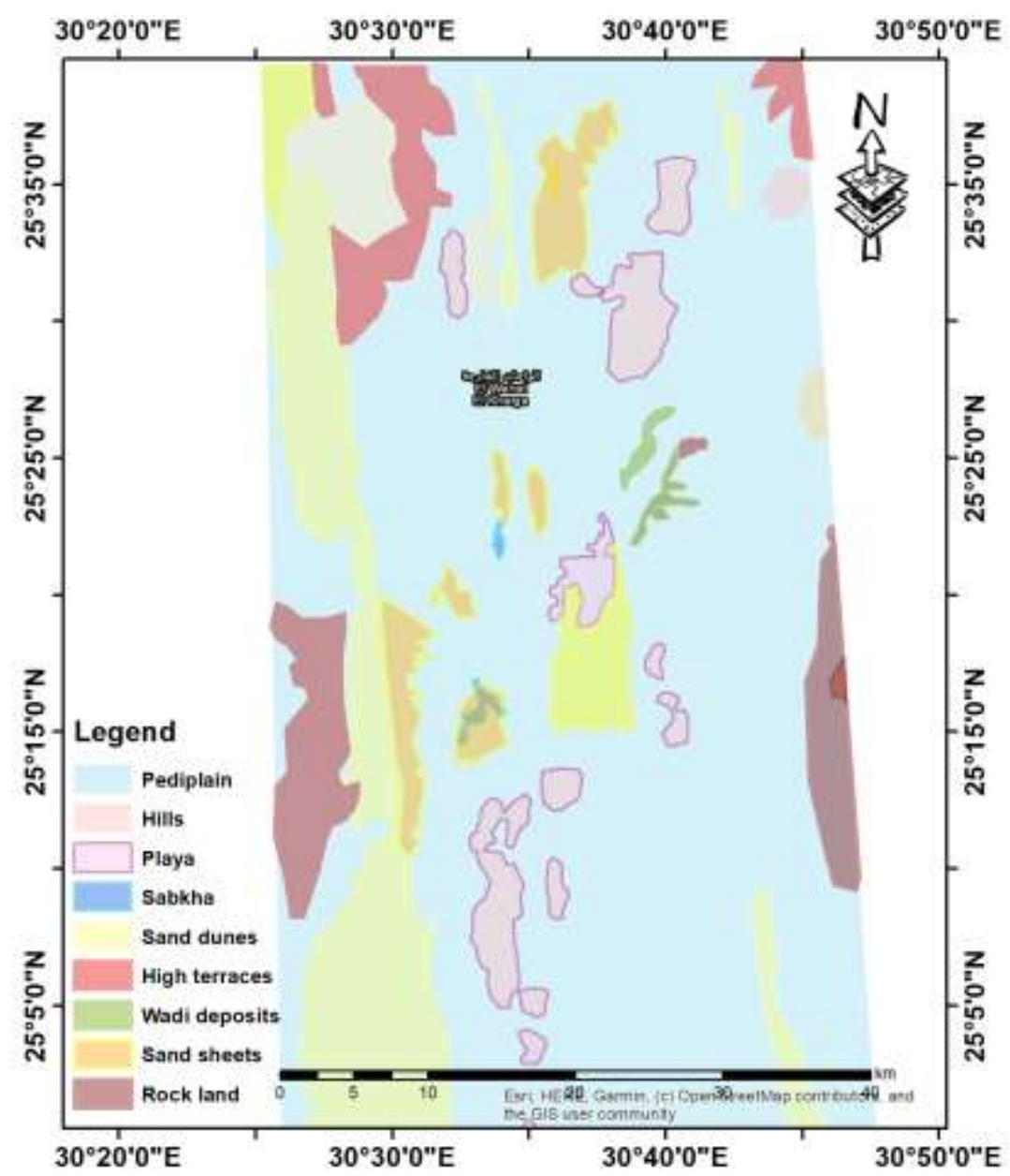

Figure (3): The main geomorphological units of the study area

\section{RESULTS AND DISCUSSION}

The studied area is occupied by three geomorphic units Table 1; namely; Pedilpain, Sand sheets and Playa. The considered region could be ordered to five regions El-Monera, Al - Sharika, El - kharga , NasserEl-thawra and Ganah - Bulaq. The morphological, physical and chemical properties of soil profiles for every area are given in the following:

\section{1- El-Monera region}

This soil unit it is represented by soil profiles 1,2 and 3 . The topography of the landscape is generally flat to almost flat with nearly level to very gently sloping surface. The soil surface is generally covered with drift sand sheet and field crops. The common features of this soil are moderate 
deep to deep $(80-150 \mathrm{~cm}$.), coarse texture sometimes with medium to fine texture surface and somewhat excessively drained to well drained. In EL-Monera village calcium carbonate contents ranged from $3.75 \%$ to $19.15 \%$, this means the soil in this location ranges from moderately calcareous to strongly calcareous. Gypsum content is very low where its content ranges from trace to $1.4 \%$, while being absent in the successive layers of most soil profiles. Electrical conductivity of the soil saturation extract varies from 0.75 to $5.19 \mathrm{dSm}^{-1}$, indicating slightly to strongly saline condition according to (FAO,2006). The large amounts of soluble salts dictate that leaching or removal of soluble salts at least beyond the root zone is a must, and this could be practiced quite easily due to the open structure of soil such as sand sheets map unit.

Table (1) Particle size distribution and textural classes of the studied soils

\begin{tabular}{|c|c|c|c|c|c|c|c|c|c|c|}
\hline Location & $\begin{array}{c}\text { Profile } \\
\text { No. }\end{array}$ & & $\begin{array}{c}\begin{array}{c}\text { Depth } \\
\text { cm }\end{array} \\
\end{array}$ & $\begin{array}{c}\mathrm{CaCO}_{3} \\
\% \\
\end{array}$ & $\begin{array}{c}\text { Gypsum } \\
\% \\
\end{array}$ & $\begin{array}{c}\text { Gravel } \\
\%\end{array}$ & \begin{tabular}{c|} 
Clay \\
$\%$
\end{tabular} & $\begin{array}{c}\text { Sand } \\
\% \\
\end{array}$ & $\begin{array}{l}\text { Silt } \\
\%\end{array}$ & $\begin{array}{c}\text { Soil } \\
\text { texture } \\
\end{array}$ \\
\hline \multirow{11}{*}{$\begin{array}{c}\text { El- } \\
\text { Moniera }\end{array}$} & \multirow{4}{*}{1} & \multirow{4}{*}{$\begin{array}{l}\text { Sand } \\
\text { sheets }\end{array}$} & 0---20 & 6.21 & tr. & n.d. & 13.26 & 63.7 & 23.04 & $\begin{array}{c}\text { Sandy } \\
\text { loam }\end{array}$ \\
\hline & & & $20-45$ & 7.23 & tr. & n.d. & 4.08 & 87.22 & 8.7 & sand \\
\hline & & & \begin{tabular}{|l|}
$45-80$ \\
\end{tabular} & 3.57 & 1.4 & 3 & 4.08 & 90.16 & 5.76 & sand \\
\hline & & & $80+$ & \multicolumn{7}{|c|}{ Water table } \\
\hline & \multirow{4}{*}{2} & \multirow{4}{*}{ Pedilpain } & 0---30 & 14.47 & tr. & n.d. & 28.56 & 57.82 & 13.62 & $\begin{array}{c}\text { Sandy } \\
\text { clay } \\
\text { loam }\end{array}$ \\
\hline & & & 30---75 & 18.72 & tr. & n.d. & 25.5 & 60.76 & 13.74 & $\begin{array}{c}\text { Sandy } \\
\text { clay } \\
\text { loam }\end{array}$ \\
\hline & & & $\begin{array}{l}75--- \\
120 \\
\end{array}$ & 17.14 & tr. & n.d. & 32.64 & 37.24 & 30.12 & $\begin{array}{l}\text { Clay } \\
\text { loam }\end{array}$ \\
\hline & & & $120+$ & \multicolumn{7}{|c|}{ Water table } \\
\hline & \multirow{3}{*}{3} & \multirow{3}{*}{ Playa } & 0--50 & 13.62 & tr. & 1 & 5.1 & 87.22 & 7.68 & sand \\
\hline & & & 50--100 & 10.28 & tr. & n.d. & 4.08 & 86.24 & 9.68 & sand \\
\hline & & & $100-150$ & 19.15 & tr. & 0.5 & 6.12 & 88.2 & 5.68 & sand \\
\hline \multirow{6}{*}{$\begin{array}{c}\text { Al - } \\
\text { Sharika }\end{array}$} & \multirow{3}{*}{4} & \multirow{3}{*}{ Pedilpain } & 0-30 & 7.66 & tr. & n.d. & 7.14 & 82.32 & 10.54 & $\begin{array}{l}\text { Loamy } \\
\text { sand }\end{array}$ \\
\hline & & & 30--90 & 5.14 & tr. & n.d. & 9.18 & 82.32 & 8.5 & $\begin{array}{c}\text { Loamy } \\
\text { sand }\end{array}$ \\
\hline & & & $90+$ & \multicolumn{7}{|c|}{ Water table } \\
\hline & \multirow{3}{*}{5} & \multirow{3}{*}{ Playa } & 0---25 & 7.66 & tr. & n.d. & 5.1 & 79.38 & 15.52 & $\begin{array}{l}\text { Sandy } \\
\text { loam }\end{array}$ \\
\hline & & & 25---85 & 10.23 & tr. & n.d. & 30.6 & 34.3 & 35.1 & $\begin{array}{l}\text { Clay } \\
\text { loam }\end{array}$ \\
\hline & & & $85+$ & \multicolumn{7}{|c|}{ Water table } \\
\hline \multirow{9}{*}{$\begin{array}{c}\text { El - } \\
\text { kharga }\end{array}$} & \multirow{5}{*}{6} & \multirow{5}{*}{ Playa } & 0---20 & 8.74 & tr. & n.d. & 5.1 & 88.2 & 6.7 & $\begin{array}{l}\text { Loamy } \\
\text { sand }\end{array}$ \\
\hline & & & $20---40$ & 8.51 & tr. & n.d. & 33.66 & 32.34 & 34 & $\begin{array}{l}\text { Clay } \\
\text { loam }\end{array}$ \\
\hline & & & 40---60 & 3.66 & tr. & n.d. & 49.98 & 29.4 & 20.62 & Clay \\
\hline & & & 60--130 & 3.43 & tr. & n.d. & 44.88 & 10.78 & 44.34 & Silty cay \\
\hline & & & 130+ & \multicolumn{7}{|c|}{ Water table } \\
\hline & \multirow{4}{*}{7} & \multirow{4}{*}{ Pedilpain } & 0---30 & 8.51 & tr. & n.d. & 10.2 & 62.72 & 27.08 & $\begin{array}{l}\text { Sandy } \\
\text { loam }\end{array}$ \\
\hline & & & 30---50 & 2.38 & tr. & n.d. & 47.94 & 29.4 & 22.66 & Clay \\
\hline & & & 50---90 & 3 & tr. & n.d. & \begin{tabular}{|l|l|}
58.14 \\
\end{tabular} & 32.34 & 9.52 & Clay \\
\hline & & & 90+ & \multicolumn{7}{|c|}{ water table } \\
\hline
\end{tabular}


Table (1)., Cont.

\begin{tabular}{|c|c|c|c|c|c|c|c|c|c|c|}
\hline Location & Profile & & Depth & СaCO3 & Gypsum & Gravel & Clay & Sand & Silt & Soil \\
\hline & No. & & $\mathrm{cm}$ & $\%$ & $\%$ & $\%$ & $\%$ & $\%$ & $\%$ & texture \\
\hline \multirow{13}{*}{$\begin{array}{c}\text { Nasser- } \\
\text { Al - } \\
\text { thawra }\end{array}$} & \multirow{5}{*}{8} & \multirow{5}{*}{ Pedilpain } & $0---25$ & 7.71 & tr. & n.d. & 36.72 & 32.34 & 30.94 & Clay loam \\
\hline & & & $25-55$ & 7.37 & 1.6 & n.d. & 7.14 & 79.38 & 13.48 & Loamy sand \\
\hline & & & $55-90$ & 2.57 & tr. & n.d. & 32.64 & 32.34 & 35.02 & Clay loam \\
\hline & & & 90-120 & $\mathbf{1 0 . 2 1}$ & tr. & n.d. & 45.9 & 7.84 & 46.26 & Silty clay \\
\hline & & & $120+$ & \multicolumn{7}{|c|}{ Water table } \\
\hline & \multirow{5}{*}{9} & \multirow{5}{*}{ Pedilpain } & 0---25 & 7.11 & tr. & 2.5 & 32.64 & 10.78 & 56.58 & $\begin{array}{c}\text { Silty clay } \\
\text { loam }\end{array}$ \\
\hline & & & $25-50$ & 13.36 & tr. & 2.5 & 32.64 & 33.32 & 34.04 & Clay loam \\
\hline & & & $50-90$ & 8.08 & 1.4 & n.d. & 34.68 & 32.34 & 32.98 & Clay loam \\
\hline & & & $90-125$ & 7.11 & tr. & 2.5 & 32.64 & 10.78 & 56.58 & Silt clay loam \\
\hline & & & $125+$ & \multicolumn{7}{|c|}{ Water table } \\
\hline & \multirow{3}{*}{10} & \multirow{3}{*}{$\begin{array}{l}\text { Sand } \\
\text { sheets }\end{array}$} & $0---30$ & 8.94 & tr. & n.d. & 6.12 & 87.22 & 6.66 & sand \\
\hline & & & $30-100$ & 5.14 & tr. & 1 & 4.08 & 86.24 & 9.68 & sand \\
\hline & & & $100-150$ & 10.64 & tr. & n.d. & 6.12 & 87.22 & \begin{tabular}{|l|}
6.66 \\
\end{tabular} & sand \\
\hline \multirow{14}{*}{$\begin{array}{c}\text { Ganah } \\
\text { and } \\
\text { Bulaq }\end{array}$} & \multirow{5}{*}{11} & \multirow{5}{*}{ Pedilpain } & 0---30 & 10.21 & tr. & n.d. & 34.68 & 30.38 & 34.94 & Clay loam \\
\hline & & & 30-70 & 10.21 & tr. & n.d. & 52.02 & 23.52 & 24.46 & Clay \\
\hline & & & $70-90$ & 0.86 & tr. & n.d. & 33.66 & 30.38 & 35.96 & Clay loam \\
\hline & & & $90--120$ & 18.85 & tr. & n.d. & 52.02 & 25.48 & 22.5 & Clay \\
\hline & & & $120+$ & \multicolumn{7}{|c|}{ Water table } \\
\hline & \multirow{4}{*}{12} & \multirow{4}{*}{ Pedilpain } & 0---25 & 8.4 & tr. & n.d. & 34.68 & 36.26 & 29.06 & Clay loam \\
\hline & & & $25-50$ & 13.11 & tr. & 2.5 & 8.16 & \begin{tabular}{|l|}
80.36 \\
\end{tabular} & \begin{tabular}{|l|}
11.48 \\
\end{tabular} & Loamy sand \\
\hline & & & $50-90$ & 0.85 & tr. & n.d. & 32.64 & 33.32 & 34.04 & Clay loam \\
\hline & & & $90+$ & \multicolumn{7}{|c|}{ Water table } \\
\hline & \multirow{5}{*}{13} & \multirow{5}{*}{ Playa } & $0---20$ & 11.49 & tr. & 1.11 & 11.22 & 62.72 & 26.06 & Sandy loam \\
\hline & & & $20-40$ & 13.62 & tr. & n.d. & 4.08 & 89.18 & \begin{tabular}{|l|}
6.74 \\
\end{tabular} & sand \\
\hline & & & $40-80$ & 4.94 & tr. & n.d. & 36.72 & 31.36 & 31.92 & Clay loam \\
\hline & & & 80-120 & 1.79 & 1.6 & n.d. & 46.92 & 6.86 & 46.22 & Silt clay \\
\hline & & & $120+$ & \multicolumn{7}{|c|}{ Water table } \\
\hline
\end{tabular}

2- Al - Sharika region

Playa and Pediplain are the main geomorphological units were represented in Al - Sharika region. The topography of the landscape is flat with a nearly level sloping surface. The common morphological characteristics of these soils are moderately deep $(85-90 \mathrm{~cm}$.), with a water table in the deepest layers. calcium carbonate contents ranged from 5.17 to $10.23 \%$ in subsurface layers, this soil consider as moderately calcareous. The texture of this village ranged from loamy sand to clay loam. $\mathrm{Al}$ - sharika village soil salinity ranges from 0.21 to $2.44 \mathrm{dSm}^{-1}$, indicating salt-free to moderately saline soils.

\section{3- El - kharga region}

The landscape has a nearly flat to nearly level sloping plain surface, which is generally covered with field crops. Most feature of this unit is pediplain and playa with moderate to deep $(90-130 \mathrm{~cm}$ ) above a water table level. The soils are often non calcareous to moderately calcareous (2.38 to $8.7 \%$ ). The EC values range between 1.3 and $6.8 \mathrm{dSm}-1$. The organic matter content is low (0.82 to $1.15 \%)$.

\section{4- Nasser-El-thawra region}

The soils represented by soil profiles 8,9 and 10, which include pediplain and sand sheets geomorphological mapping unit. Topography 
of the landscape is generally flat to gently undulating with flat to gently sloping surface. The common characteristics of these soils are deep profiles where the effective soil depth varies from $125-150 \mathrm{~cm}$, soil texture throughout the entire depth of the studied soil profiles is coarse to fine texture. Table (1) shows that these soils are non-calcareous to strongly calcareous, where calcium carbonate content varies widely from 2.57 to $13.6 \%$. Gypsum is absent in most soil layers. Soil salinity ranges from non-saline to moderately saline $\left(0.2\right.$ to $\left.4.46 \mathrm{dsm}^{-1}\right)$. Organic matter and macronutrients levels in the uppermost soil layers, table (2) show that organic matter content is low and ranges from 0.69 to $0.82 \%$.

Table (2) Chemical properties of the studied soils ( $\mathrm{mg} / \mathrm{kg}$ )

\begin{tabular}{|c|c|c|c|c|c|c|c|c|c|c|c|c|c|}
\hline Location & \begin{tabular}{|c|} 
Profile. \\
No.
\end{tabular} & $\begin{array}{l}\text { Depth } \\
\text { (cm) })\end{array}$ & $\mathbf{p H}$ & \begin{tabular}{|c|}
$\mathbf{E C}$ \\
$\mathbf{d S m}^{-1}$
\end{tabular} & \begin{tabular}{|l|}
$\mathbf{N a}^{+}$ \\
\end{tabular} & $\mathbf{K}^{+}$ & $\mathbf{C a}^{++}$ & $\mathbf{M g}^{++}$ & $\mathrm{Cl}^{-1}$ & $\mathrm{SO}_{4}{ }^{-1}$ & $\mathrm{Co}_{3}$ & $\mathrm{HCO}_{3}^{-}$ & $\frac{.0 M}{\%}$ \\
\hline \multirow[t]{9}{*}{ El-Moniera } & \multirow[t]{3}{*}{1} & $0-20$ & 7.4 & 2.3 & 7.7 & 1.1 & 4.1 & 3.3 & 10.9 & 2.8 & $\overline{0.0}$ & 2.5 & \multirow[t]{3}{*}{0.43} \\
\hline & & $20-45$ & 7.3 & 0.9 & 2.6 & 0.3 & 1.5 & 0.7 & 3.5 & 0.9 & 0.0 & 0.7 & \\
\hline & & $45-80$ & 7.2 & 2.0 & 5.6 & 0.4 & 3.7 & 1.8 & 6.5 & 3.8 & 0.0 & 1.1 & \\
\hline & \multirow[t]{3}{*}{2} & 0 - 30 & 7.7 & 0.8 & 1.9 & 0.2 & 1.3 & 1.6 & 3.0 & 0.1 & 0.0 & 1.9 & \multirow[t]{3}{*}{0.36} \\
\hline & & $30-75$ & 7.4 & 1.9 & 3.8 & 0.5 & 6.5 & 2.0 & 0.4 & 11.4 & 0.0 & 1.0 & \\
\hline & & $75-12$ & 7.4 & 5.2 & \begin{tabular}{|l|}
11.2 \\
\end{tabular} & 1.4 & 18.5 & 9.2 & 12.1 & 24.7 & 0.0 & 3.5 & \\
\hline & \multirow[t]{3}{*}{3} & $0-50$ & 7.4 & 1.6 & 5.5 & 0.6 & 3.2 & 1.6 & 3.1 & 6.8 & 0.0 & 1.1 & \multirow[t]{3}{*}{1.28} \\
\hline & & $50-100$ & 7.4 & 1.3 & 3.7 & 13.0 & 2.1 & 1.7 & 2.3 & 16.7 & 0.0 & 1.4 & \\
\hline & & $100-150$ & 8.1 & 1.3 & 2.7 & 0.2 & 2.0 & 0.6 & 1.7 & 3.2 & 0.0 & 0.7 & \\
\hline \multirow[t]{4}{*}{ Al - sharika } & \multirow[t]{2}{*}{4} & $0-30$ & 8.4 & 0.9 & 2.4 & 0.1 & 3.3 & 2.3 & 3.0 & 3.6 & 0.0 & 1.5 & \multirow[t]{2}{*}{1.08} \\
\hline & & $30-90$ & 7.8 & 1.4 & 0.7 & 0.0 & 0.4 & 0.2 & 0.3 & 0.8 & 0.0 & 0.1 & \\
\hline & 5 & $0-25$ & 7.9 & 0.2 & 6.3 & 33.7 & 13.7 & 8.2 & 8.2 & 47.5 & 0.0 & 6.3 & 1.15 \\
\hline & & $25-85$ & 7.8 & 2.4 & \begin{tabular}{|l|}
22.7 \\
\end{tabular} & 0.7 & 10.0 & 9.9 & 18.0 & 18.5 & 0.0 & 6.9 & \\
\hline El -kharga & 6 & $0-20$ & 7.5 & 6.8 & 7.3 & 0.3 & 1.0 & 2.1 & 3.5 & 5.5 & 0.0 & 1.7 & 1.15 \\
\hline & & $20-40$ & 7.5 & 2.0 & 6.4 & 0.3 & 4.4 & 4.4 & 5.4 & 8.4 & 0.0 & 1.6 & \\
\hline & & $40-60$ & 7.5 & 3.6 & 9.6 & 0.4 & 8.0 & 5.6 & 5.8 & 16.5 & 0.0 & 1.2 & \\
\hline & & $60-130$ & 7.6 & 3.3 & 8.9 & 0.4 & 5.6 & 4.6 & 4.5 & 13.8 & 0.0 & 1.7 & \\
\hline & 7 & 0 - 30 & 7.8 & 3.7 & 9.1 & 0.3 & 1.7 & 1.1 & 10.2 & 1.7 & 0.0 & 0.3 & 0.82 \\
\hline & & $30-50$ & 7.9 & 3.4 & 2.6 & 0.1 & 2.0 & 1.3 & 1.2 & 3.8 & 0.0 & 0.9 & \\
\hline & & $50-90$ & 7.6 & 1.4 & 6.2 & 0.2 & 1.0 & 0.7 & 3.0 & 4.2 & 0.0 & 1.0 & \\
\hline Nass & 8 & $0-25$ & 7.8 & 1.5 & \begin{tabular}{|l|}
18.8 \\
\end{tabular} & 0.9 & 2.2 & 1.7 & 5.3 & 16.6 & 0.0 & 1.7 & 0.69 \\
\hline & & $25-55$ & 7.5 & 4.6 & 3.0 & 0.6 & 3.5 & 3.9 & 1.7 & 8.4 & 0.0 & 1.0 & \\
\hline & & $55-90$ & 7.5 & 1.5 & 8.2 & 0.2 & 1.2 & 2.2 & 2.0 & 8.8 & 0.0 & 1.1 & \\
\hline & & $90-120$ & 7.4 & 2.1 & 5.7 & 0.6 & 1.8 & 3.4 & 3.2 & 7.5 & 0.0 & 0.9 & \\
\hline & 9 & $0-25$ & 7.2 & 1.9 & 5.2 & 0.3 & 10.4 & 6.5 & 2.6 & 14.3 & 0.0 & 5.4 & 0.82 \\
\hline & & $25-50$ & 7.3 & 3.5 & 7.0 & 0.7 & 3.2 & 2.6 & 3.2 & 7.7 & 0.0 & 2.6 & \\
\hline & & $50-90$ & 7.4 & 2.4 & 4.7 & 0.6 & 2.7 & 2.3 & 0.2 & 8.6 & 0.0 & 1.6 & \\
\hline & & $90-125$ & 7.6 & 1.6 & 5.2 & 0.3 & 10.4 & 6.5 & 2.6 & 14.3 & 0.0 & 5.4 & 0.82 \\
\hline & 10 & $0-30$ & 7.4 & 3.5 & 0.5 & 0.1 & 0.3 & 0.3 & 0.9 & 0.2 & 0.0 & 0.1 & 1.15 \\
\hline & & $30-100$ & 7.1 & 0.2 & 0.0 & 0.0 & 2.1 & 1.3 & 2.4 & 0.4 & 0.0 & 1.0 & \\
\hline & & $100-150$ & 7.3 & 1.0 & 3.3 & 0.2 & 2.3 & 3.4 & 7.6 & 0.9 & 0.0 & 0.8 & \\
\hline Ganah and & 11 & $0-30$ & 7.2 & 1.4 & 5.7 & 0.5 & 3.5 & 1.8 & 5.2 & 5.5 & 0.0 & 0.8 & 0.49 \\
\hline & & $30-70$ & 7.3 & 1.8 & 9.5 & 0.8 & 3.0 & 1.7 & 8.7 & 2.2 & 0.0 & 4.1 & \\
\hline & & $70-90$ & 7.4 & 3.3 & 8.2 & 1.1 & 5.3 & 5.1 & 5.4 & 12.2 & 0.0 & 2.0 & \\
\hline & & $90-120$ & 8.0 & 2.3 & 6.1 & 0.6 & 4.3 & 4.1 & 5.9 & 6.9 & 0.0 & 2.3 & \\
\hline & 12 & $0-25$ & 8.1 & 9.0 & \begin{tabular}{|l|}
29.2 \\
\end{tabular} & 1.0 & 13.3 & 10.0 & 14.8 & \begin{tabular}{|l|}
28.9 \\
\end{tabular} & 0.0 & 9.7 & 1.02 \\
\hline & & $25-50$ & 7.8 & 1.9 & 4.8 & 0.3 & 3.1 & 1.6 & 4.6 & 1.2 & 0.0 & 4.0 & \\
\hline & & $50-90$ & 7.8 & 2.9 & 8.7 & 0.4 & 3.9 & 1.3 & 4.9 & 9.0 & 0.0 & 0.3 & \\
\hline & 13 & $0-20$ & 7.5 & 2.0 & \begin{tabular}{|l|}
7.3 \\
\end{tabular} & \begin{tabular}{ll|}
0.3 \\
\end{tabular} & 1.0 & 2.1 & 3.5 & 5.5 & 0.0 & 1.7 & 1.15 \\
\hline & & $20-40$ & 7.5 & 3.6 & 6.4 & 0.3 & 4.4 & 4.4 & 5.4 & 8.4 & 0.0 & 1.6 & \\
\hline & & $40-80$ & 7.5 & 3.3 & 9.6 & 0.4 & 8.0 & 5.6 & 5.8 & 16.4 & 0.0 & 1.2 & \\
\hline & & $80-120$ & 7.5 & 3.7 & 8.9 & 0.4 & 5.6 & 4.6 & 4.5 & 13.4 & 0.0 & 1.7 & \\
\hline
\end{tabular}




\section{5- Ganah - Bulaq region}

This soil mapping unit represented by soil profiles 11,12 and 13 . Topography of the landscape is generally almost flat to flat with nearly level sloping surface. The common characteristics of these soils which represented playa and pediplain units are moderate to deep soils (90-120 $\mathrm{Cm})$. Gypsum content varies from trace to $1.6 \%$, while being absent in the other soil profiles. Also, table (1) shows that these soils are noncalcareous to extremely calcareous, where calcium carbonate content ranges widely from 0.86 to $18.85 \%$. Electrical conductivity values of most of these soils ranges from 1.35 to $9.02 \mathrm{dSm}^{-1}$, indicating slightly saline to extremely saline. The cationic composition of the soil saturation extract of all soil layers is dominated with $\mathrm{Na}^{+}$followed by $\mathrm{Ca}^{++}$and/or $\mathrm{Mg}^{++}$and $\mathrm{K}^{+}$, while $\mathrm{Cl}^{-}$and $\mathrm{SO}_{4}^{--}$followed by $\mathrm{HCO}_{3}^{-}$dominated the anionic composition. Regarding the levels of organic matter and macronutrients in most surface layers, data in table (2) show that organic matter content is low and ranges from 0.49 to $1.15 \%$.

\section{Land Evaluation}

Evaluation of the soils represented by the studied profiles was carried out using land evaluation systems outlined by Sys, and Verheye (1978) and Micro LEIS DSS. Noteworthy to mention that evaluation of these characteristics is accomplished for gravity irrigation using good quality water. Results obtained are discussed in the following: -

\section{Currently land capability}

Land evaluation method was used to evaluate actual land suitability, which relates the suitability of land units for a specific use under present condition.

\section{land capability by Sys and Verheye (1978) system and CERVATANA model}

Applying this system, concerning the physico-chemical land characteristics for irrigation, to soils of the study area, Table (3) reveals that these soils could be placed, according to the calculated $\mathrm{Ci}$ values, into the following orders and classes: marginally suitable (S3) and currently not suitable (N1), the suitability index for irrigation (Ci) ranges is 18.47 to $49.10 \%$. While land capability classes using CERVATANA model area marginally suitable (S3 I), the main limitations were soil salinity, drainage, soil texture and soil depth

\section{Potential land capability}

Potential land suitability will be presented, which relates to the suitability of the land units after investigation of the major improvements in the light of the economic possibilities available. Potential land capability and suitability refers to the capability of units for a defined use, after specified major improvements have been completed where necessary such as: the most limiting chemical factor being considered is 
soil salinity which can be removed by reclaiming these soils through leaching, especially as the good quality irrigation water is available and applied management programs, which can decrease the salinity. From the results in Table 3, it is evident that all soils represented by most of the studied profiles belongs to S2 and S3 according to Sys and Verheye system, while (S2 I) according to CERVATANA model

Table (3) Current and potential land capability of the profiles represented geomorphological units

\begin{tabular}{|c|c|c|c|c|c|c|c|c|c|}
\hline \multirow{3}{*}{\begin{tabular}{|l|} 
Loca- \\
tion
\end{tabular}} & Pro- & Geomorpholo & \multicolumn{4}{|c|}{ Currently land capability } & \multicolumn{3}{|c|}{ Potential land capability } \\
\hline & No. & units & \multicolumn{4}{|c|}{$\begin{array}{c}\text { Land capability Sys and Verheye and } \\
\text { CERVATANA model }\end{array}$} & \multicolumn{3}{|c|}{$\begin{array}{c}\text { Land capability Sys and Verheye and } \\
\text { CERVATANA model }\end{array}$} \\
\hline & & & $\mathrm{C}$ & & $\begin{array}{l}\text { CERVT } \\
\text { ANA }\end{array}$ & main limitations & Proposed managements & $\mathbf{C i}$ & $\begin{array}{c}\text { CER } \\
\text { VTA } \\
\text { NA }\end{array}$ \\
\hline \multirow{3}{*}{ } & 1 & Pedilpain & 43.86 & S3 & S3I & \begin{tabular}{|l|}
$\begin{array}{l}\text { Drainage, soil } \\
\text { salinity, }\end{array}$ \\
\end{tabular} & \begin{tabular}{|l|} 
Leaching, Tolerant crops \\
such as quinoa
\end{tabular} & 64.13 & S2I \\
\hline & 2 & Playa & 39.24 & S3 & S3I & $\begin{array}{l}\text { soil depth and } \\
\text { soil texture }\end{array}$ & $\begin{array}{|lll|}\begin{array}{l}\text { Improvement of } \\
\text { drainage and }\end{array} & \text { the } \\
\end{array}$ & 57.38 & S2I \\
\hline & 3 & Sand sheets & 42.32 & S3 & S3I & & Irrigation management & 44.55 & S2I \\
\hline \multirow{4}{*}{ 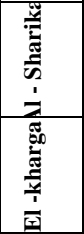 } & 4 & Pedilpain & 44.74 & S3 & S3I & $\begin{array}{l}\text { Drainage, soil } \\
\text { salinity }\end{array}$ & Deep plowing to improve & 65.41 & S2I \\
\hline & 5 & Playa & 31.40 & S3 & S3I & and soil depth & \begin{tabular}{|l}
$\begin{array}{l}\text { soil permeability and } \\
\text { moisture availability. }\end{array}$ \\
\end{tabular} & 45.90 & S2I \\
\hline & 6 & Playa & 41.12 & S3 & S3I & \begin{tabular}{|l|l|}
$\begin{array}{l}\text { Drainage and } \\
\text { soil salinity }\end{array}$ \\
\end{tabular} & $\begin{array}{l}\text { Organic fertilization to } \\
\text { improve permeability }\end{array}$ & 48.09 & S2I \\
\hline & 7 & Pedilpain & 37.28 & S3 & S3I & & \begin{tabular}{|l|l|} 
Applying modern \\
irrigation systems
\end{tabular} & 54.51 & S2I \\
\hline \multirow{3}{*}{ 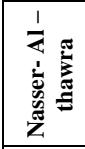 } & 8 & Pedilpain & 41.42 & S3 & S3I & \begin{tabular}{|l|}
$\begin{array}{l}\text { Drainage, soil } \\
\text { salinity }\end{array}$ \\
\end{tabular} & & 60.56 & S2I \\
\hline & 9 & Pedilpain & 49.10 & S3 & S3I & \begin{tabular}{|l|}
$\begin{array}{l}\text { Drainage, soil } \\
\text { salinity }\end{array}$ \\
\end{tabular} & & 64.60 & S2I \\
\hline & 10 & Sand sheets & 18.47 & N1 & S3I & and soil texture & & 38.90 & S2I \\
\hline \multirow{3}{*}{ 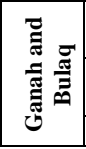 } & 11 & Pedilpain & 39.24 & S3 & S3I & \begin{tabular}{|l|}
$\begin{array}{l}\text { Drainage, soil } \\
\text { salinity, }\end{array}$ \\
\end{tabular} & & 57.38 & S2I \\
\hline & 12 & Pedilpain & 33.24 & S3 & S3I & \begin{tabular}{|l|} 
soil depth and \\
soil texture
\end{tabular} & & 51.30 & S2I \\
\hline & 13 & Playa & 44.48 & S3 & S3I & & & 68.64 & S2I \\
\hline
\end{tabular}

Marginally suitable (S3), Moderately suitable (S2) $\mathbf{C i}=$ Capability index

Agricultural soil suitability (Almagra model)

Potential land suitability will be presented, which relates to the suitability of the land units after investigation of the major improvements in the light of the economic possibilities available. Potential land capability and suitability refers to the capability of units for a defined use, after specified major improvements have been completed where necessary such as: the most limiting chemical factor being considered is soil salinity which can be removed by reclaiming these soils through leaching, especially as the good quality irrigation water is available and applied management programs, which can decrease the salinity. The area under investigation has been divided into two relative suitability classes; suitable ( $\mathrm{S} 2$ class) and marginally suitable (S3 class) table4 a and b. The main limitations were useful depth, texture, drainage, salinity, carbonate, and sodium saturation. 
Table (4): Agricultural soil suitability for of the profiles represented geomorphological units

a) Annual crops and Tolerant crops such as (Quinoa)

\begin{tabular}{|c|c|c|c|c|c|c|c|c|c|c|c|}
\hline \multirow{3}{*}{ Location } & \multirow{3}{*}{$\begin{array}{c}\text { Profile } \\
\text { No. }\end{array}$} & \multirow{3}{*}{\begin{tabular}{|c|} 
Geomorphological \\
units \\
\end{tabular}} & \multicolumn{8}{|c|}{ Almagra model: Agricultural soil suitability } & \multirow{3}{*}{\begin{tabular}{|c|} 
Tolerant \\
crops \\
Quinoa
\end{tabular}} \\
\hline & & & \multicolumn{8}{|c|}{ Annual crops } & \\
\hline & & & Wheat & Maize & Melon & Potatoes & Soybean & Cotton & Sunflower & Sugar beet & \\
\hline \multirow{3}{*}{$\sum_{\frac{1}{5}}^{\frac{\pi}{5}}$} & 1 & Pedilpain & S3t & S3t & S3t & S3t & S3t & S3t & S3t & S3t & S2t \\
\hline & 2 & Playa & S2ta & S3a & S2csa & S2csa & S2tsa & S2c & S2tsa & S2t & S1 \\
\hline & 3 & Sand sheets & S3t & S3t & S3t & S3t & S3t & S3t & S3t & S3t & S2 \\
\hline \multirow{2}{*}{ 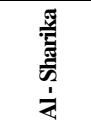 } & 4 & Pedilpain & S3t & S3t & S3t & S3t & S3t & S3t & S3t & S3t & S1 \\
\hline & 5 & Playa & S2tsa & S3a & S3s & S2csa & S2tsa & S2c & S2tsa & S2t & S1 \\
\hline \multirow{2}{*}{ 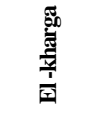 } & 6 & Playa & S3t & S3t & S3t & S3t & S3t & S3t & S3t & S3t & S1 \\
\hline & 7 & Pedilpain & S3t & S3t & S3t & S3t & S3t & S3t & S3t & S3t & S1 \\
\hline \multirow{3}{*}{ 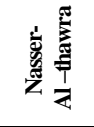 } & 8 & Pedilpain & S3t & S3t & S3t & S3t & S3t & S3t & S3t & S3t & S1 \\
\hline & 9 & Pedilpain & S3t & S3t & S3t & S3t & S3t & S3t & S3t & S3t & S1 \\
\hline & 10 & Sand sheets & S3t & S3t & S3t & S3t & S3t & S3t & S3t & S3t & S1 \\
\hline \multirow{3}{*}{ 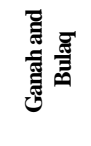 } & 11 & Pedilpain & S3t & S3t & S3t & S3t & S3t & S3t & S3t & S3t & S2t \\
\hline & 12 & Pedilpain & S2tsa & S3a & S3s & S2csa & S2tsa & S2c & S2tsa & S2t & S1 \\
\hline & 13 & Playa & S3t & S3t & S3t & S3t & S3t & S3t & S3t & S3t & S1 \\
\hline
\end{tabular}

b) Semi-annual and perennial crops

\begin{tabular}{|c|c|c|c|c|c|c|}
\hline & & & \multicolumn{4}{|c|}{ Almagra model: Agricultural soil suitability } \\
\hline \multirow{2}{*}{ Location } & Profile & Geomorphological & \multicolumn{4}{|c|}{ Semi-annual and perennial crops } \\
\hline & No. & units & Alfalfa & Peach & Citrus & Olive \\
\hline \multirow{3}{*}{ 空 } & 1 & Pedilpain & S3t & S2tdc & S2tdc & S2tds \\
\hline & 2 & Playa & S2tsa & S2des & S2des & S2dsa \\
\hline & 3 & Sand sheets & S3t & S2tdc & S2tdc & S2tds \\
\hline \multirow{2}{*}{ 文萦 } & 4 & Pedilpain & S3t & S2tdc & S2tdc & S2tds \\
\hline & 5 & Playa & S2tsa & S3s & S3s & S3s \\
\hline \multirow{2}{*}{ 穴兽 } & 6 & Playa & S3t & S2tdc & S2tdc & S2tds \\
\hline & 7 & Pedilpain & S3t & S2tdc & S2tdc & S2tds \\
\hline \multirow{3}{*}{ 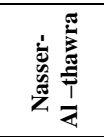 } & 8 & Pedilpain & S3t & S2tdc & S2tdc & S2tds \\
\hline & 9 & Pedilpain & S3t & S2tdc & S2tdc & S2tds \\
\hline & 10 & Sand sheets & S3t & S2tdc & S2tdc & S2tds \\
\hline \multirow{3}{*}{ 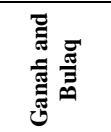 } & 11 & Pedilpain & S3t & S2tdc & S2tdc & S2tds \\
\hline & 12 & Pedilpain & S2tsa & S3s & S3s & S3s \\
\hline & 13 & Playa & S3t & S2tdc & S2tdc & S2tds \\
\hline
\end{tabular}

S3 = marginally suitable, $N 1=$ currently not suitable, $N 2=$ permantly not suitable , ca, calcium carbonate content,$d=$ soil depth $g=$ gupsum content, $t=$ soil texture , $s=$ soil salnity 


\section{Total heavy metals in the studied soils}

Data in Table (5) Show the content of total heavy metals in the studied soils in New -Valley In all locations the elements under study $(\mathrm{Cr}, \mathrm{Cu}, \mathrm{Zn}, \mathrm{Ni}, \mathrm{Pb}$, and $\mathrm{Cd}$ ) within international limits except $\mathrm{Cd}$ metal in Bulaq village in the surface layer $(0-30 \mathrm{~cm}) 5.3 \mathrm{mg} / \mathrm{kg}$. According the Maximum permissible level of trace elements, reported by (KabataPendias and Pendias 2001) are Cd (cadmium) $5 \mathrm{mg} / \mathrm{kg}$, Co (cobalt) 50 $\mathrm{mg} / \mathrm{kg}, \mathrm{Cr}$ (chromium) $100 \mathrm{mg} / \mathrm{kg}$, Cu (copper) $100 \mathrm{mg} / \mathrm{kg}$, Ni (nickel) $100 \mathrm{mg} / \mathrm{kg}$, Pb (lead) $100 \mathrm{mg} / \mathrm{kg}$, and Zn (zinc) $300 \mathrm{mg} / \mathrm{kg}$.

- Cr metal varies from $18.1 \mathrm{mg} / \mathrm{kg}$ in subsurface layer in profile 1 .(El- Moniera village) to $84.2 \mathrm{mg} / \mathrm{kg}$ in the surface layer in profile 11. ( Bulaq village) and follows irregular distribution in all profiles in the studied soils except profile 4 . The $\mathrm{Cr}$ metal content increasing by increasing the depth of profile.

- $\quad \mathrm{Cu}$ metal varies $3.9 \mathrm{mg} / \mathrm{kg}$ in subsurface layer in profile 1(20 $45 \mathrm{~cm})$ in ( $\mathrm{El}-$ Monera village) to $39.7 \mathrm{mg} / \mathrm{kg}$ in the deepest layer in profile 8 (Nasser $\mathrm{Al}$ - thawra village). Also, $\mathrm{Cu}$ metal follows irregular distribution in profiles 1 . But in profiles 4,6 , and 8 the content of $\mathrm{Cu}$ metal increased by increasing of depth of profiles. In profile 11 the content of $\mathrm{Cu}$ metal decreasing by increasing the depth of profile in the studied soils.

- $\mathrm{Zn}$ metal content varies from $14.7 \mathrm{mg} / \mathrm{kg}$ in subsurface layer in profile $1(20-45 \mathrm{~cm})$ to $66.9 \mathrm{mg} / \mathrm{kg}$ in the surface layer in profile 11. The distribution of $\mathrm{Zn}$ in all profile's irregular distribution Except profile 4 the content is fixed $21.8 \mathrm{mg} / \mathrm{kg}$ in two layers.

- $\quad \mathrm{Ni}$ metal content varies from $4.9 \mathrm{mg} / \mathrm{kg}$ in subsurface layer in profile 1 to $33.9 \mathrm{mg} / \mathrm{kg}$ in the deepest layer in profile 8 . the disruption of Ni metal is irregular except profile 4. The content of $\mathrm{Ni}$ metal increased by increasing the depth in most of the studied profiles.

- $\mathrm{Pb}$ metal content is the lower value in the deepest layer in profile 1. The value $1.4 \mathrm{mg} / \mathrm{kg}$ and the highest value in the surface layer in profile $11(18.3 \mathrm{mg} / \mathrm{kg})$. the disruption in profiles 1,4 , and 8 the content of $\mathrm{Pb}$ metal decreasing by increasing the depth of profiles. But in profiles 6,11 the distribution is irregular

- Cd metal content varies from 0.16 in the surface layer in profile 1 to $0.75 \mathrm{mg} / \mathrm{kg}$ in the surface layer in profile 4 . In all profiles distribution of $\mathrm{Cd}$ metal is irregular except profile 4 the content increase by increasing the depth of the profile. 
Table (5) Total heavy metals content $(\mathrm{mg} / \mathrm{kg})$ in the studied soils.

\begin{tabular}{|c|c|c|c|c|c|c|c|c|c|}
\hline Location & $\begin{array}{c}\text { Profile } \\
\text { NO. }\end{array}$ & $\begin{array}{l}\text { Depth. } \\
\text { (Cm) }\end{array}$ & $\mathrm{Cr}$ & $\mathrm{Cu}$ & $\mathbf{Z n}$ & $\mathbf{F e}$ & $\mathbf{N i}$ & $\mathbf{P b}$ & Cd \\
\hline \multirow{3}{*}{$\begin{array}{l}\text { El- } \\
\text { Monera }\end{array}$} & \multirow[t]{3}{*}{1} & $0-20$ & 22.7 & 7.4 & $\begin{array}{l}38.7 \\
\end{array}$ & 6513 & 5.6 & 2.6 & 0.16 \\
\hline & & $20-45$ & $\begin{array}{ll}18.1 \\
\end{array}$ & 3.9 & 14.7 & 4782 & 4.9 & 2.1 & 0.25 \\
\hline & & $45-80$ & 29.1 & 7.4 & 25.8 & 7030 & 6.6 & 1.4 & 0.23 \\
\hline \multirow{2}{*}{$\begin{array}{l}\text { Al - } \\
\text { Sharika }\end{array}$} & \multirow[t]{2}{*}{4} & $0-30$ & 24.2 & 5.8 & 21.8 & 5505 & 4.9 & 2.6 & 0.75 \\
\hline & & $30-90$ & 26.5 & 10.6 & 21.8 & 6522 & 6.5 & 1.7 & 0.23 \\
\hline \multirow{3}{*}{$\begin{array}{l}\text { El - } \\
\text { kharga }\end{array}$} & \multirow[t]{3}{*}{6} & $0-20$ & 50.2 & 22.5 & 44.5 & 14880 & 20.3 & 4.9 & 0.21 \\
\hline & & $20-40$ & 59.6 & 25.6 & 57.8 & 18210 & 27.6 & 2.9 & 0.23 \\
\hline & & $40-60$ & 53.6 & 27.5 & 46.8 & 15040 & 22.2 & 8.8 & 0.22 \\
\hline \multirow{4}{*}{$\begin{array}{l}\text { Nasser- } \\
\text { Al - } \\
\text { thawra }\end{array}$} & \multirow[t]{4}{*}{8} & $0-25$ & $\begin{array}{l}60.2 \\
\end{array}$ & \begin{tabular}{|l|l|}
30.9 \\
\end{tabular} & 60.7 & 16350 & $\begin{array}{l}28.7 \\
\end{array}$ & 5.7 & 0.65 \\
\hline & & $25-55$ & 55.9 & 26.8 & 52.9 & 16120 & 24.6 & 5.4 & 0.28 \\
\hline & & \begin{tabular}{|c|}
$55-90$ \\
\end{tabular} & $\begin{array}{l}68.0 \\
\end{array}$ & 34.2 & $\begin{array}{l}62.8 \\
\end{array}$ & 20250 & $\begin{array}{l}30.9 \\
\end{array}$ & 4.7 & 0.36 \\
\hline & & $90-120$ & 73.6 & 39.7 & 66.8 & 19880 & $\begin{array}{l}33.9 \\
\end{array}$ & 4.2 & 0.55 \\
\hline \multirow{4}{*}{$\begin{array}{l}\text { Ganah } \\
\text { and } \\
\text { Bulaq }\end{array}$} & \multirow[t]{4}{*}{11} & 0-30 & 84.2 & 37.6 & 66.9 & 20870 & 31.6 & 18.3 & 0.23 \\
\hline & & 30-70 & $\begin{array}{l}56.8 \\
\end{array}$ & 33.7 & \begin{tabular}{|l|}
53.8 \\
\end{tabular} & 10510 & 25.8 & 2.9 & 0.34 \\
\hline & & $70-90$ & 66.9 & 33.3 & 59.6 & 18620 & 29.2 & 1.6 & 0.64 \\
\hline & & $90-120$ & 65.4 & 33.9 & 58.9 & 15930 & 28.2 & 7.2 & 0.56 \\
\hline $\begin{array}{l}\text { M.P.L } \\
(\mathbf{m g} / \mathbf{k g})\end{array}$ & & & 100.0 & 100.0 & 300.0 & & 100.0 & 100.0 & 5.0 \\
\hline
\end{tabular}

Data in Table (6) show the concentration of extractable heavy metals in the studied soils. All heavy metals concentrations are lower than the maximum permissible level. The maximum permissible level of extractable of trace metals in soil are the following, $\mathrm{Pb}-6,0 \mathrm{mg} / \mathrm{kg}$ and $\mathrm{Cr}-6,0 \mathrm{mg} / \mathrm{kg} \mathrm{Ni}-4,0 \mathrm{mg} / \mathrm{kg} \mathrm{Co}-5 . \mathrm{mg} / \mathrm{kg} \mathrm{Zn}-23,0 \mathrm{mg} / \mathrm{kg} \mathrm{Cu}-3,0$ and $\mathrm{Cd} 3.0 \mathrm{mg} / \mathrm{kg}$

- Cr metal varies from $0.22 \mathrm{mg} / \mathrm{kg}$ in subsurface layer in profile 8 to $0.88 \mathrm{mg} / \mathrm{kg}$ in the surface layer in profile 6 . In profiles $1,8,11$ the concentration is an irregular distribution while in profile 4 the content of $\mathrm{Cr}$ metal increased by increased the depth of profile, but in profile 6 the content decreeing by increasing the depth of profile.

- $\quad \mathrm{Cu}$ metal varies from $0.19 \mathrm{mg} / \mathrm{kg}$ in deepest layer in profile 1 to $1.86 \mathrm{mg} / \mathrm{kg}$ in deepest layer in profile 6 . In profile 8 , the extractable of $\mathrm{Cu}$ metal is an irregular distribution. But in profile 4,6. the extractable of $\mathrm{Cu}$ increased by increasing the depth of the profiles. But in profile 11 the extractable of $\mathrm{Cu}$ is decreasing by increasing of profile.

- $\mathrm{Zn}$ metal varies from 0.21 in the deepest layer in profile 1.to 1.81 $\mathrm{mg} / \mathrm{kg}$ in the surface layer in profile 1. In all profiles the disruption of $\mathrm{Zn}$ metal increased by increasing the depth in the most of the studied profiles.

- $\quad$ Ni metal the extractable varies from 0.04 in the deepest layer in profile 1 to 0.89 in the subsurface layer in profile 8 . In profiles $6,8,11$. The disruption is an irregular. But in profiles 1,4 the $\mathrm{Ni}$ extract decreased by increasing the depth of the profile. 
- $\mathrm{Pb}$ metal the extractable ranges from $0.04 \mathrm{mg} / \mathrm{kg}$ in the deepest layer in profile 1 to $0.86 \mathrm{mg} / \mathrm{kg}$ in the deepest layer in profile 11 . In profiles $6,8,11$ the distribution is an irregular. But in profile 1 $\mathrm{Pb}$ metal the extract decreased by increasing the depth of profiles and in profile $4 \mathrm{~Pb}$ metal extract increased by increasing the depth of profile.

- Cd metal extract varies from $0.1 \mathrm{mg} / \mathrm{kg}$ in the deepest layer in profile $8(55-90 \mathrm{~cm})$ to $0.76 \mathrm{mg} / \mathrm{kg}$ in the sub-surface layer in profile 8. metal extract in profiles $1,6,8$ is an irregular distribution. But in profiles 4,11 the extract decreased by increasing the depth of profile.

Table (6) Chemical extractable heavy metals content in the studied soils.

\begin{tabular}{|c|c|c|c|c|c|c|c|c|c|}
\hline \multirow[t]{2}{*}{ Location } & Profile & Depth. & $\mathbf{C r}$ & $\mathrm{Cu}$ & $\mathbf{Z n}$ & $\mathbf{F e}$ & $\mathbf{N i}$ & $\mathbf{P b}$ & Cd \\
\hline & NO. & $(\mathbf{C m})$ & \multicolumn{7}{|c|}{$(\mathrm{mg} / \mathrm{kg})$} \\
\hline \multirow[t]{3}{*}{ El-Monera } & \multirow[t]{3}{*}{1} & $0-20$ & 0.71 & 1.69 & 1.81 & 17.1 & 0.22 & 0.37 & 0.07 \\
\hline & & $20-45$ & 0.41 & 0.84 & $\mathbf{0 . 5 8}$ & 11.3 & 0.06 & 0.28 & 0.44 \\
\hline & & $45-80$ & 0.42 & 0.19 & 0.21 & 11.2 & 0.04 & 0.04 & 0.13 \\
\hline \multirow[t]{2}{*}{ Al - Sharika } & \multirow[t]{2}{*}{4} & $0-30$ & 0.42 & 1.16 & 0.98 & 8.63 & 0.24 & 0.34 & 0.46 \\
\hline & & $30-90$ & 0.74 & 1.68 & 0.95 & 26.2 & 0.17 & 0.35 & 0.04 \\
\hline \multirow[t]{3}{*}{ El -kharga } & \multirow[t]{3}{*}{6} & $0-20$ & 0.88 & 1.18 & 1.18 & 81.2 & 0.13 & 0.71 & 0.18 \\
\hline & & $20-40$ & 0.64 & 1.42 & 1.18 & 138.6 & 0.15 & 0.65 & 0.04 \\
\hline & & $40-60$ & 0.19 & 1.86 & 1.06 & 123.8 & 0.14 & 0.37 & 0.12 \\
\hline \multirow{4}{*}{$\begin{array}{l}\text { Nasser- Al - } \\
\text { thawra }\end{array}$} & \multirow[t]{4}{*}{8} & $0-25$ & 0.44 & 0.96 & 1.10 & 139 & 0.25 & 0.63 & 0.55 \\
\hline & & $25-55$ & 0.22 & 0.99 & 1.13 & 120.6 & 0.89 & 0.24 & 0.76 \\
\hline & & $55-90$ & 0.26 & 0.58 & 1.25 & 141.3 & 0.86 & 0.75 & 0.01 \\
\hline & & $90-120$ & 0.27 & 0.96 & 1.21 & 97.5 & 0.50 & 0.28 & 0.26 \\
\hline \multirow{4}{*}{$\begin{array}{l}\text { Ganah and } \\
\text { Bulaq }\end{array}$} & \multirow[t]{4}{*}{11} & 0-30 & 0.42 & 1.68 & 1.09 & 103 & 0.55 & 0.65 & 0.66 \\
\hline & & 30-70 & 0.52 & 0.98 & 1.34 & 75.58 & 0.20 & 0.75 & 0.42 \\
\hline & & $70-90$ & 0.62 & 0.63 & 1.59 & 36.72 & 0.26 & 0.86 & 0.11 \\
\hline & & $90-120$ & 0.28 & 0.42 & 1.36 & 73.4 & 0.42 & 0.23 & 0.07 \\
\hline M.P.L (mg/kg) & & & 6.0 & 3.0 & 23.0 & & 4.0 & 6.0 & 3.0 \\
\hline
\end{tabular}

Data in table (7) Listed trace elements content ( $\mathrm{mg} / \mathrm{kg})$ of plants in the studied soils. Cu metal content varies from $0.90 \mathrm{mg} / \mathrm{kg}$ in leaves of Been in Al - Sharika village to 5.09 in root of Quinoa in Bulak village the distribution is vertical by depth of profiles and below the maximum permissible level according to FAO, (2006). Zn metal content the lower value $1.02 \mathrm{mg} / \mathrm{kg}$ in Wheat grain in profile 1 and the highest value is 5.38 $\mathrm{mg} / \mathrm{kg}$ in root of Qunioa in profile 11, and below the (M.P.L ) . Cr metal content in plants in the studied soils the lower value in 0.69 in wheat grain profile 1, but the higher value is 4.02 in the root of Qunioa in profile 11. Ni metal content in plants the lowest value is $0.53 \mathrm{mg} / \mathrm{kg}$ in the fruit of Qunioa in profile 11 and the higher value is $2.81 \mathrm{mg} / \mathrm{kg}$ in the root of Been in profile 4, but the content in the studied soils above the (M.P.L) in profiles 1.4,6,8. pb metal content varies from 0.06 in fruit of Qunioa to $1.25 \mathrm{mg} / \mathrm{kg}$ in root of Onion in profile 8 . All the content below the (M.P. L). Cd metals varies from $0.06 \mathrm{mg} / \mathrm{kg}$ in the wheat grain in 
profile 1 to $2.56 \mathrm{mg} / \mathrm{kg}$ in the root of Qunioa in profile 11. and some contents above the (M.P.L) profiles 4,6, 8 and 11.)

Table (7) Trace elements content $(\mathrm{mg} / \mathrm{kg}$ ) of plants in the studied soils.

\begin{tabular}{|c|c|c|c|c|c|c|c|c|}
\hline Location. & $\begin{array}{c}\text { Profile } \\
\text { No. }\end{array}$ & $\begin{array}{l}\text { Types of } \\
\text { plants }\end{array}$ & $\mathrm{Cu}$ & $\mathrm{Zn}$ & $\mathrm{Cr}$ & $\mathbf{N i}$ & $\mathbf{P b}$ & Cd \\
\hline \multirow[t]{2}{*}{ El-Mounira } & \multirow[t]{2}{*}{1} & $\begin{array}{l}\text { Wheat } \\
\text { stalk }\end{array}$ & 2.81 & 2.61 & 1.13 & 2.15 & 0.92 & 0.09 \\
\hline & & $\begin{array}{l}\text { Wheat } \\
\text { grain }\end{array}$ & 1.10 & 1.02 & 0.69 & 0.91 & 0.55 & 0.06 \\
\hline \multirow[t]{3}{*}{ El-Sarika } & \multirow[t]{3}{*}{4} & $\begin{array}{l}\text { Root of } \\
\text { Been }\end{array}$ & 3.13 & 3.66 & 2.20 & 2.81 & 1.02 & 0.13 \\
\hline & & $\begin{array}{ll}\text { Stalk } \\
\text { Been }\end{array}$ & 1.09 & 2.11 & 1.15 & 1.05 & 0.83 & 0.81 \\
\hline & & $\begin{array}{l}\text { Leaves of } \\
\text { Been }\end{array}$ & 0.90 & 1.12 & 0.92 & 0.80 & 0.55 & 0.33 \\
\hline \multirow[t]{3}{*}{ El - kharga } & \multirow[t]{3}{*}{6} & $\begin{array}{l}\text { Root of } \\
\text { Quinoa }\end{array}$ & 4.22 & 4.52 & 3.56 & 2.41 & 1.06 & 1.55 \\
\hline & & $\begin{array}{c}\text { Leaves of } \\
\text { Quinoa }\end{array}$ & 3.24 & 3.12 & 1.25 & 1.09 & 0.89 & 1.01 \\
\hline & & $\begin{array}{l}\text { Fruit of } \\
\text { Quinoa }\end{array}$ & 1.26 & 1.56 & 0.89 & 0.95 & 0.53 & 0.76 \\
\hline \multirow[t]{2}{*}{$\begin{array}{l}\text { Nasser-Al - } \\
\text { thawra }\end{array}$} & \multirow[t]{2}{*}{8} & $\begin{array}{c}\text { Root of } \\
\text { onion }\end{array}$ & 3.14 & 4.52 & 2.01 & 2.11 & 1.25 & 1.08 \\
\hline & & $\begin{array}{c}\text { Stalk of } \\
\text { onion }\end{array}$ & 2.55 & 1.99 & 1.11 & 0.74 & 0.59 & 0.09 \\
\hline \multirow[t]{3}{*}{$\begin{array}{l}\text { Ganah and } \\
\text { Bulaq }\end{array}$} & \multirow[t]{3}{*}{11} & $\begin{array}{l}\text { Root of } \\
\text { Quinoa }\end{array}$ & 5.09 & 5.38 & 4.02 & 1.06 & 1.03 & 2.56 \\
\hline & & $\begin{array}{c}\text { Leaves of } \\
\text { Quinoa }\end{array}$ & 3.17 & 3.57 & 3.21 & 0.92 & 0.84 & 1.84 \\
\hline & & $\begin{array}{l}\text { Fruit of } \\
\text { Quinoa }\end{array}$ & 1.87 & 1.95 & 1.28 & 0.53 & 0.06 & 0.46 \\
\hline $\begin{array}{l}\text { M.P.L } \\
(\mathrm{mg} / \mathrm{kg})\end{array}$ & & & 40.0 & 60.0 & 20.0 & 1.5 & 5.0 & 0.3 \\
\hline
\end{tabular}

\section{Translocation (TF) and Biological accumulation coefficient}

Translocation factors ( TF) transfer the metals from soil or roots to shoot (Ma, et al 2001) $\mathrm{TF}=$ Metal in shoot $/$ Metal in soil or root .

BAC : Determine the ability of the plant to up take the metal from soil. BAC : metal in shoot / metal in soil .

Data in table (8) represent the translocation factor and biological accumulation factor of $(\mathrm{Cu})$ metal in the vegetables' which grown in the studied soil. Translocation factor in all vegetables in all profiles $>1$ and ( BAF ) $>1$ this means occur transfer and accumulate high percent of Copper metal from contaminated soil to vegetables' which considered as a hyper accumulators (Blalyock and Huang (2005). Variation of metal translocation and uptake due to different concentration of metal in soil, organic matter, $\mathrm{pH}$, in soil, age of plant as mentioned (Khan, et al 2015).

Translocation factor (TF) and biological accumulation coefficient (BAC) of $\mathrm{Cu}, \mathrm{Zn}$ and $\mathrm{Cr}(\mathrm{mg} / \mathrm{kg})$ Table (8). Wheat stalks the translocation factor (TF) and bioaccumulation coefficient (BAC) for $\mathrm{Cu}, \mathrm{Zn}$ and $\mathrm{Cr}$ in $\mathrm{El}-$ 
Mounira village (Profile 1) both factors $>1$, this means to the wheat stalk is accumulated by $\mathrm{Cu}, \mathrm{Zn}$ and $\mathrm{Cr}$. But in wheat grain both factors $<1 \mathrm{in} \mathrm{Cu}$ and $\mathrm{Zn}$ metals. These results indicated that no accumulation in grains by $\mathrm{Cu}$, $\mathrm{Zn}$ and $\mathrm{Cr}$ thus the wheat grain is safe in food chain. However, roots of Been in El-Sarika village the translocation factor and bioaccumulation coefficient (BAC) for $\mathrm{Cu}, \mathrm{Zn}$ and $\mathrm{Cr}>1$ so the roots of Bean are hyper accumulators by three elements. But in stalk and leaves of Been both factors $<1$ in $\mathrm{Cu}$ metal, these results indicated that accumulation by $\mathrm{Cu}$ metal. While in $\mathrm{Zn}$ and $\mathrm{Cr}$ metals both factors $>1$ thus the accumulation occur by few degrees. Roots and leaves of Qunioa in El - kharga village (profile 6) both factor TF and BAC > 1, in three elements these results indicated that the roots and leaves of Qunioa consider as a hyper accumulator by $\mathrm{Cu}, \mathrm{Zn}$ and $\mathrm{Cr}$ metals and reached the toxicity indirectly to the food chain. While in fruits of Qunioa both factor $<1$, indicated that no accumulation by $\mathrm{Cu}$ in fruits of Qunioa and become safe to food chain. While the fruits in $\mathrm{Zn}$ and $\mathrm{Cr}$ metals the both factor $>1$ by few degrees, but the accumulation is very small. Roots and stalk of Onion Nasser-Al -thawra village (profile 8) translocation and Bioaccumulation coefficient $(\mathrm{BAC})>1$ by higher degrees, these data indicated the Onion as a hyper accumulator by $\mathrm{Cu}, \mathrm{Zn}$ and $\mathrm{Cr}$ metals and must be reached directly to the food chain and become hazard to the healthy. Roots, leaves and fruits of Qunioa in Ganah and Bulaq in (profile 11) the both factor $>1$, these data indicated that the Qunioa plants are hyperaccumulators by $\mathrm{Cu}, \mathrm{Zn}$ and $\mathrm{Cr}$ metals.

Table (8): Translocation factor (TF) and biological accumulation coefficient (BAC) of $\mathrm{Cu}, \mathrm{Zn}$ and $\mathrm{Cr}(\mathrm{mg} / \mathrm{kg})$

\begin{tabular}{|c|c|c|c|c|c|c|c|c|c|c|c|c|c|c|}
\hline Location & $\begin{array}{l}\text { Pro. } \\
\text { No. }\end{array}$ & $\begin{array}{l}\text { Types of } \\
\text { plants }\end{array}$ & $\begin{array}{c}\mathrm{Cu} \\
\text { in } \\
\text { soil }\end{array}$ & $\begin{array}{c}\text { Cu } \\
\text { in } \\
\text { plants }\end{array}$ & $\begin{array}{c}\text { T.F } \\
\text { of } \mathbf{C u}\end{array}$ & $\begin{array}{c}\text { BAC } \\
\text { of } \\
\text { Cu }\end{array}$ & $\begin{array}{c}\text { Zn } \\
\text { in } \\
\text { soil }\end{array}$ & $\begin{array}{c}\text { Zn } \\
\text { in } \\
\text { plants }\end{array}$ & $\begin{array}{c}\text { T.F } \\
\text { of } \\
\mathrm{Zn}\end{array}$ & $\begin{array}{l}\text { BAC } \\
\text { of } \mathbf{Z n}\end{array}$ & $\begin{array}{c}\mathrm{Cr} \text { in } \\
\text { soil }\end{array}$ & $\begin{array}{c}\mathrm{Cr} \\
\text { in } \\
\text { plants }\end{array}$ & \begin{tabular}{|c|} 
T.F \\
of $\mathbf{C r}$
\end{tabular} & $\begin{array}{l}\text { BAC } \\
\text { of } \mathrm{Cr}\end{array}$ \\
\hline \multirow{2}{*}{$\begin{array}{c}\text { El- } \\
\text { Mounira }\end{array}$} & & Wheat stalk & \multirow[b]{2}{*}{1.69} & 2.81 & 1.66 & 1.66 & \multirow[b]{2}{*}{1.18} & 2.61 & 1.44 & 1.44 & \multirow[b]{2}{*}{0.71} & 1.13 & \begin{tabular}{|l|}
1.59 \\
\end{tabular} & 1.59 \\
\hline & & Wheat grain & & 1.10 & 0.65 & 0.65 & & 1.02 & 0.56 & 0.56 & & 0.69 & \begin{tabular}{|l|}
0.97 \\
\end{tabular} & 0.97 \\
\hline \multirow{3}{*}{$\begin{array}{c}\text { El- } \\
\text { Sarika }\end{array}$} & \multirow[b]{3}{*}{4} & Root of Been & \multirow[b]{3}{*}{1.51} & 3.13 & 2.07 & 2.07 & \multirow[b]{3}{*}{0.96} & 3.66 & 3.81 & 3.81 & \multirow[b]{3}{*}{0.63} & 2.20 & 3.49 & 3.49 \\
\hline & & Stalk of Been & & 1.09 & 0.72 & 0.72 & & 2.11 & 2.20 & 2.20 & & 1.15 & 1.83 & 1.83 \\
\hline & & $\begin{array}{c}\text { Leaves of } \\
\text { Been }\end{array}$ & & 0.90 & 0.60 & 0.60 & & 1.12 & 1.16 & 1.16 & & 0.92 & 1.46 & 1.46 \\
\hline \multirow{3}{*}{$\begin{array}{c}\text { El - } \\
\text { kharga }\end{array}$} & \multirow{3}{*}{6} & $\begin{array}{l}\text { Root of } \\
\text { Quinoa }\end{array}$ & \multirow{3}{*}{1.49} & 4.22 & 2.83 & 2.83 & \multirow{3}{*}{1.14} & 4.52 & 3.96 & 3.96 & \multirow{3}{*}{0.57} & 3.56 & 6.25 & 6.25 \\
\hline & & $\begin{array}{c}\text { Leaves of } \\
\text { Quinoa }\end{array}$ & & 3.24 & 2.17 & 2.17 & & 3.12 & 2.74 & 2.74 & & 1.25 & 2.19 & 2.19 \\
\hline & & $\begin{array}{l}\text { Fruit of } \\
\text { Quinoa }\end{array}$ & & 1.26 & 0.85 & 0.85 & & 1.56 & 1.37 & 1.37 & & 0.89 & 1.56 & 1.56 \\
\hline \multirow{2}{*}{$\begin{array}{c}\text { Nasser- } \\
\text { Al - } \\
\text { thawra }\end{array}$} & & Root of onion & \multirow[b]{2}{*}{0.25} & 3.14 & .56 & .56 & \multirow[b]{2}{*}{1.10} & 4.52 & 4.11 & 4.11 & \multirow[b]{2}{*}{0.44} & 2.01 & .57 & 1.57 \\
\hline & & Stalk of onion & & 2.55 & 10.20 & 10.20 & & 1.99 & 1.81 & 1.81 & & 1.11 & 2.52 & 2.52 \\
\hline \multirow{3}{*}{$\begin{array}{c}\text { Ganah } \\
\text { and Bulaq }\end{array}$} & \multirow{3}{*}{11} & $\begin{array}{l}\text { Root of } \\
\text { Quinoa }\end{array}$ & \multirow{3}{*}{0.96} & 5.09 & 5.30 & 5.30 & \multirow{3}{*}{1.32} & 5.38 & 4.08 & 4.08 & \multirow{3}{*}{0.45} & 4.02 & 8.93 & 8.93 \\
\hline & & $\begin{array}{c}\text { Leaves of } \\
\text { Quinoa }\end{array}$ & & 3.17 & 3.30 & $\mathbf{3 . 3 0}$ & & 3.57 & 2.70 & 2.70 & & 3.21 & 7.13 & 7.13 \\
\hline & & $\begin{array}{l}\text { Fruit of } \\
\text { Quinoa }\end{array}$ & & 1.87 & 1.94 & 1.94 & & 1.95 & 1.48 & 1.48 & & 1.28 & 2.84 & 2.84 \\
\hline
\end{tabular}

TF : metals in shoot /metals in soil ( Or Root) BAF : metal in shoot /metals in soil . (Ma, et al 2001) 
Data in table (9) listed the translocation factor (TF) and biological accumulation coefficient (BAC) of $\mathrm{Ni}, \mathrm{pb}$ and $\mathrm{Cd}(\mathrm{mg} / \mathrm{kg})$ in the studied soils. Wheat stalk and grain the translocation factor (TF) and Bioaccumulation coefficient (BAC) for $\mathrm{Ni}, \mathrm{pb}$ and $\mathrm{Cd}$ in El-Mounira village (Profile 1) both factors $>1$ this means to the wheat stalk and grain are hyper -accumulators by $\mathrm{Ni}, \mathrm{pb}$ and $\mathrm{Cd}$ so must be reached directly or indirectly to the food chain. But in wheat grain both factors $<1$ in $\mathrm{Cd}$ metals, these results indicated that an accumulation in grains by $\mathrm{Cd}$, thus the wheat grain are safe in food chain. Roots, leaves and stalk of Been in El-Sarika village (profile 4) the translocation factor and Bioaccumulation coefficient (BAC) for $\mathrm{Ni}, \mathrm{pb}$ and $\mathrm{Cd}>1$ so the roots, leaves and stalk of faba bean are hyper accumulators by three elements. But in the leaves of Been both factors $<1$ in $\mathrm{Cd}$ metal, these data indicated that no accumulation by $\mathrm{Cd}$ metal. Roots leaves and fruits of Qunioa in $\mathrm{El}-$ kharga village (profile 6) both factor $\mathrm{TF}$ and $\mathrm{BAC}>1$ in $(\mathrm{Ni}, \mathrm{pb}, \mathrm{Cd})$ elements thus the roots leaves and fruits of Qunioa as an hyper accumulators by $\mathrm{Ni}, \mathrm{pb}$ and $\mathrm{Cd}$ metals and reached the toxicity directly or indirectly to the food chain. Except in fruits of Qunioa both factor $<1$ so no accumulation by $\mathrm{pb}$ in fruits of Qunioa and become safe to food chain.

Table (9): Translocation factor (TF) and biological accumulation coefficient (BAC) of $\mathrm{Ni}, \mathrm{pb}$ and $\mathrm{Cd}(\mathrm{mg} / \mathrm{kg})$

\begin{tabular}{|c|c|c|c|c|c|c|c|c|c|c|c|c|c|c|}
\hline Location & $\begin{array}{l}\text { Pro. } \\
\text { No. }\end{array}$ & $\begin{array}{c}\text { Types of } \\
\text { plants }\end{array}$ & $\begin{array}{c}\mathrm{Ni} \\
\text { in } \\
\text { soil }\end{array}$ & $\begin{array}{c}\mathbf{N i} \\
\text { in } \\
\text { plant } \\
\mathrm{s}\end{array}$ & $\begin{array}{c}\mathrm{T} . \mathrm{F} \\
\text { of } \mathrm{Ni}\end{array}$ & $\begin{array}{c}\text { BAC } \\
\text { of } \\
\mathbf{N i}\end{array}$ & $\begin{array}{c}\mathrm{Pb} \\
\text { in } \\
\text { soil }\end{array}$ & $\begin{array}{c}\mathrm{Pb} \\
\text { in } \\
\text { plant } \\
\mathrm{s}\end{array}$ & $\begin{array}{c}\text { T.F } \\
\text { of } \\
P b\end{array}$ & $\begin{array}{c}\text { BAC } \\
\text { of } \\
\mathrm{Pb}\end{array}$ & $\begin{array}{c}\text { Cd } \\
\text { in } \\
\text { soil }\end{array}$ & $\begin{array}{c}\text { Cd } \\
\text { in } \\
\text { plants }\end{array}$ & $\begin{array}{c}\text { T.F } \\
\text { of } \\
\text { Cd }\end{array}$ & $\begin{array}{l}\text { BAC } \\
\text { of Cd }\end{array}$ \\
\hline \multirow{2}{*}{$\begin{array}{c}\text { El- } \\
\text { Mounira }\end{array}$} & \multirow[t]{2}{*}{1} & Wheat stalk & \multirow[b]{2}{*}{0.22} & 2.15 & 9.77 & 9.77 & \multirow[b]{2}{*}{0.37} & 0.92 & 2.49 & 2.49 & \multirow[b]{2}{*}{0.07} & 0.09 & 1.29 & 1.29 \\
\hline & & Wheat grain & & 0.91 & 4.14 & 4.14 & & 0.55 & 1.49 & 1.49 & & 0.06 & 0.86 & 0.86 \\
\hline \multirow[t]{3}{*}{ El-Sarika } & \multirow[t]{3}{*}{4} & Root of Been & \multirow{3}{*}{0.20} & 2.81 & 14.05 & 14.05 & \multirow{3}{*}{0.35} & 1.02 & 2.91 & 2.91 & \multirow{3}{*}{0.18} & 0.81 & 4.50 & 4.50 \\
\hline & & Stalk of Been & & 1.05 & 5.25 & 5.25 & & 0.83 & 2.37 & 2.37 & & 0.33 & 1.83 & 1.83 \\
\hline & & $\begin{array}{l}\text { Leaves of } \\
\text { Been }\end{array}$ & & 0.80 & 4.00 & 4.00 & & 0.55 & 1.57 & 1.57 & & 0.13 & 0.72 & 0.72 \\
\hline \multirow[t]{3}{*}{$\begin{array}{c}\text { EI - } \\
\text { kharga }\end{array}$} & \multirow[t]{3}{*}{6} & $\begin{array}{l}\text { Root of } \\
\text { Quinoa }\end{array}$ & \multirow[t]{3}{*}{0.14} & 2.41 & 17.21 & 17.21 & \multirow[t]{3}{*}{0.58} & 1.06 & 1.83 & 1.83 & \multirow[t]{3}{*}{0.18} & 1.55 & 8.61 & 8.61 \\
\hline & & $\begin{array}{c}\text { Leaves of } \\
\text { Ouinoa }\end{array}$ & & 1.09 & 7.79 & 7.79 & & 0.89 & 1.53 & 1.53 & & 1.01 & 5.61 & 5.61 \\
\hline & & $\begin{array}{c}\text { Fruit of } \\
\text { Quinoa }\end{array}$ & & 0.95 & 6.79 & 6.79 & & 0.53 & 0.91 & 0.91 & & 0.76 & 4.22 & 4.22 \\
\hline \multirow{2}{*}{$\begin{array}{c}\text { Nasser-Al } \\
\text {-thawra }\end{array}$} & \multirow[t]{2}{*}{8} & Root of onion & \multirow[b]{2}{*}{0.96} & 2.11 & 3.27 & 3.27 & \multirow[b]{2}{*}{0.63} & 1.25 & 1.98 & 1.98 & \multirow[b]{2}{*}{0.76} & 1.08 & 0.83 & 0.82 \\
\hline & & Stalk of onion & & 0.74 & 2.65 & 2.65 & & 0.59 & 0.94 & 0.94 & & 0.09 & 0.12 & 0.12 \\
\hline \multirow{3}{*}{$\begin{array}{c}\text { Ganah } \\
\text { and } \\
\text { Bulaq }\end{array}$} & \multirow[t]{3}{*}{11} & $\begin{array}{l}\text { Root of } \\
\text { Quinoa }\end{array}$ & \multirow[t]{3}{*}{0.47} & 1.06 & 2.25 & 2.25 & \multirow[t]{3}{*}{0.83} & 1.03 & 1.24 & 1.24 & \multirow[t]{3}{*}{0.66} & 2.56 & 3.88 & 3.88 \\
\hline & & $\begin{array}{c}\text { Leaves of } \\
\text { Quinoa }\end{array}$ & & 0.92 & 1.96 & 1.96 & & 0.84 & 1.01 & 1.01 & & 1.84 & 2.79 & 2.79 \\
\hline & & $\begin{array}{l}\text { Fruit of } \\
\text { Quinoa }\end{array}$ & & 0.53 & 1.13 & 1.13 & & 0.06 & 0.07 & 0.07 & & 0.46 & 0.70 & 0.70 \\
\hline
\end{tabular}

TF : metals in shoot /metals in soil ( Or Root) BAF : metal in shoot /metals in soil . (Ma, et al 2001)

For roots and stalk of Onion Nasser-Al -thawra village (profile 8) translocation and bioaccumulation coefficient (BAC) $>1$ in $\mathrm{Ni}$ and $\mathrm{pb}$ metals by higher degree so the Onion as a hyper-accumulator by $\mathrm{Ni}, \mathrm{pb}$ and $\mathrm{Cd}$ metals and must be reached directly to the food chain and become 
hazarded to the healthy. Except the stalk of Onion, no accumulation by $\mathrm{pb}$ and $\mathrm{Cd}$ metals. Roots, leaves and fruits of Qunioa in Ganah and Bulaq in (profile 11) the both factor $>1$ thus the Qunioa plants are hyperaccumulators by $\mathrm{Ni}, \mathrm{pb}$ and $\mathrm{Cd}$ metals. But the fruits of Qunioa both factors < 1 so no accumulation of $\mathrm{Ni}$, pb and $\mathrm{Cd}$ in the fruits of Qunioa in the studied soils

\section{Water Wells Suitability for Irrigation}

The conductivity of irrigation water is between 585.0 and $926.0 \mu \mathrm{S}$ $\mathrm{cm}-1$, with an average of $728.0 \mu \mathrm{S} \mathrm{cm}-1$, indicating non-saline to moderate salinity. The conductivity results in Table $\mathbf{1 0}$ show that the salinity of all irrigation wells is less than $1,000 \mu \mathrm{S} \mathrm{cm}-1$, and the SAR is less than 10. These results indicated that quality irrigation water is good. Heavy metal contents viz., $\mathrm{Mn}, \mathrm{Zn}, \mathrm{Cu}, \mathrm{Fe}, \mathrm{Ni}, \mathrm{Co}, \mathrm{Pb}, \mathrm{Cd}$ and $\mathrm{Cr}$ in water samples were determined using inductively coupled plasma atomic emission spectroscopy (ICP-AES). From the results given, it appears that a large part of the heavy metals is in the protected range of the water system, while the iron and manganese groups are expected to increase, yet inside the protected scope of water system.

Table (10): Chemical properties of water irrigation samples in the studied soils (mg/l ).

\begin{tabular}{|c|c|c|c|c|c|c|c|c|c|c|c|c|}
\hline Location & $\mathbf{p H}$ & $\mathbf{E C}$ & $\begin{array}{l}\text { TDS, } \\
\text { mg/l }\end{array}$ & $\begin{array}{l}\mathrm{Ca}, \\
\mathrm{mg} / \mathrm{l}\end{array}$ & $\begin{array}{l}\mathrm{Mg}, \\
\mathrm{mg} / \mathrm{l}\end{array}$ & $\begin{array}{l}\mathrm{Na}, \\
\mathrm{mg} / \mathrm{l}\end{array}$ & $\begin{array}{c}\mathbf{K}, \\
\mathbf{m g} / \mathrm{l}\end{array}$ & $\begin{array}{l}\mathrm{CO}_{3}, \\
\mathrm{mg} / \mathrm{l}\end{array}$ & $\begin{array}{c}\mathrm{HCO}_{3}, \\
\mathrm{mg} / \mathrm{l}\end{array}$ & $\begin{array}{l}\mathrm{SO}_{4}, \\
\mathrm{mg} / \mathrm{l}\end{array}$ & $\begin{array}{l}\mathrm{Cl}, \\
\mathrm{mg} / \mathrm{l}\end{array}$ & SAR \\
\hline El Monera & 8 & 728 & 428 & 30.51 & 8.89 & 98 & 28 & Nil & 207.4 & 41.082 & 117.45 & 4.01 \\
\hline El Sherka & 7.9 & 585 & 337 & 28.06 & 10.48 & 68 & 25 & Nil & 176.9 & 19.174 & 97.87 & 2.78 \\
\hline El kargah & 6.4 & 822 & \begin{tabular}{|l|}
496.3 \\
\end{tabular} & 44 & 31.4 & 50 & 38 & Nil & 85.4 & 172.7 & 117.4 & 1.41 \\
\hline Nasser & 6.2 & 926 & 573.2 & 51.4 & 34.6 & 65 & 36 & Nil & 85.4 & 201.6 & 141.9 & 1.72 \\
\hline Bulaq & 7.2 & 709 & 428 & 29.01 & 11.8 & 96 & 22 & Nil & 195.2 & 74.022 & 97.87 & 3.8 \\
\hline \multicolumn{13}{|c|}{ Trace and heavy elements } \\
\hline Location & \multicolumn{2}{|c|}{$\begin{array}{c}C d, \\
m g / l\end{array}$} & $\begin{array}{c}\mathrm{Co} \\
\mathrm{mg} / \mathrm{l}\end{array}$ & & $\begin{array}{l}\mathrm{g}, \\
g / l\end{array}$ & \multicolumn{2}{|c|}{$\begin{array}{c}\mathrm{Cu}, \\
\mathrm{mg} / \mathrm{l}\end{array}$} & $\begin{array}{c}F e \\
m g / l\end{array}$ & $\begin{array}{c}M a \\
m g / l\end{array}$ & $\begin{array}{l}M o, \\
m g / l\end{array}$ & $\begin{array}{l}\mathrm{Ni}, \\
m g / l\end{array}$ & $\begin{array}{c}\mathrm{Zi}, \\
m g / l\end{array}$ \\
\hline El Monerah & \multicolumn{2}{|c|}{0.0365} & $<0.001$ & & 475 & \multicolumn{2}{|c|}{0.2507} & 1.919 & 0.0179 & 0.1463 & 0.0048 & 0.0077 \\
\hline El Sherka & \multicolumn{2}{|c|}{0.0176} & $<0.001$ & & .01 & \multicolumn{2}{|c|}{$\begin{array}{l}0.0207 \\
\end{array}$} & 0.2377 & 0.0168 & 0.0939 & $<0.002$ & 0.0099 \\
\hline El kargah & \multicolumn{2}{|c|}{$<0.0006$} & $<0.001$ & & .01 & \multicolumn{2}{|c|}{0.017} & 0.1253 & 0.4676 & 0.2234 & $\mathbf{0 . 0 3 2 7}$ & 0.0155 \\
\hline Nasser & \multicolumn{2}{|c|}{0.0356} & $<0.001$ & & .01 & \multicolumn{2}{|c|}{$<0.006$} & $\mathbf{0 . 1 3 8 7}$ & 0.5467 & $<0.001$ & $\mathbf{0 . 0 7 7}$ & 0.0259 \\
\hline Bulak & \multicolumn{2}{|c|}{0.0255} & $<0.001$ & 0.0 & 602 & \multicolumn{2}{|c|}{0.0134} & 0.2435 & 0.1166 & 0.1318 & $<0.002$ & 0.0563 \\
\hline
\end{tabular}

\section{CONCLUSION}

Based on geomorphological units of the studied soil profiles, the studied area could be classified to (pedilpain, playa and sand sheets) soil mapping units. Except for sand sheets unit, the high level of water table in the lands representing the different soil units is a problem that necessitates drainage and periodic analyses of soil salinity. Consulting the land suitability system for certain crops, MICROLESS reveals that the study area is suitable (S2) and moderately suitable (S3) in some soils for a wide range of crops such as annual and semi-annual and perennial 
crops. Quinoa is one of the crops that is suitable for different soil units, and it is more productive in pedilpain and playa and less productive in sandy lands. Total heavy metals contents in the studied soils in pediplain, playa and sand sheets units $(\mathrm{Cr}, \mathrm{Cu}, \mathrm{Zn}, \mathrm{Ni}, \mathrm{Pb}$, and $\mathrm{Cd})$ within international limits except $\mathrm{Cd}$ metal in some surface layers. The greater part of the chose yields like wheat, Faba beans, onions and quinoa, the aftereffects of the weighty metals content of root, stalk, leaves and fruit of Quinoa showed that they are in safe limits. The results presented in the study show an accumulation of certain elements, whether in the roots or leaves, and sometimes in grains such as beans, wheat and quinoa. Despite the accumulation of these elements such as, nickel, cadmium and lead, they are within safe limits for human consumption.

\section{ACKNOWLEDGEMENTS}

The research presented in this paper has been done within the project "Smart agriculture project and the development of quinoa cultivation systems in the New Valley- Egypt. which is funded by International Center for Bio-saline Agriculture (ICBA) and Desert Research Center, Egypt. The authors appreciate the efforts and assistance of . Dr. Shreen Mansour, the Principal Investigator of this project.

\section{REFERENCES}

Abdelhafez, A.A. ; M.H. Abbas ; M.H. Kenawy ; A. Noureldeen ; H. Darwish ; A.M. Ewis and M.H. Hamed (2021): Evaluation of underground water quality for drinking and irrigation purposes in New Valley Governorate, Egypt. Environmental Technology \& Innovation, 22: 101486.

Abou-Korin, A.A. (2002): Sustainability requirements of desert development in Egypt: The case of New Valley Region. Journal of Engineering Science.

Alloway, B. J. (2009): Soil factors associated with zinc deficiency in crops and humans. Environmental Geochemistry and Health, 31(5): 537-548.

Black, C.A. (1983):"Methods of soil analysis". Part 1. Agron series (9)Am. Soc. Agron. Mad. Wise., U.S.A.

Blalyock, M.J. and J.W. Huang (2005): Pytoextraction of metals in pyoremediation of toxic metals using plant to clean up the environment. (Eds.: I. Raskin, B.D. Ensley viley, New York.

Day, P. and C.Black (1982): In methods of soil analysis, part 2. Page, AL, et al., Eds, 935-951.

Demirezen, D. and A. Aksoy (2004): Accumulation of heavy metals in Typha angustifolia (L.) and Potamogeton pectinatus (L.) living in Sultan Marsh (Kayseri, Turkey). Chemosphere, 56(7): 685-696. 
El-Marsafawy, S. ; N. Bakr ; T. Elbana and H. El-Ramady (2019): Climate. In The Soils of Egypt (pp. 69-92). Springer, Cham.

El-Sankary, M.M. (2002): Geological, sedimentological and radioactivity studies of the Quaternary sediments, El Kharga Depression, Western Desert, Egypt. Ph.D. Thesis, Ain Shams Univ., Cairo, Egypt, 241 p.

Ezzelarab, M. ; A. Hassoup ; A.A. El-Ata ; A.M. Lala ; D. Hassan and A. Adly (2021): Integration of local soil effect into the assessment of seismic hazard at the Kharga Oasis, Western Desert, Egypt. Scientific African, 12: e00747.

FAO, (1990): Guidelines for Soil Profile Description. Third edition (revised). Soil Resources, Management and Conservation Service,Land and Water Development Division.FAO,Rome.

FAO, (2006): Guidelines for soil description. Food and Agriculture Organization of the United Nations, Rome .

Gad, A. (2013): Assessment and mapping of Desertification sensitivity in some of the western desert oases, Egypt, based on remote sensing and GIS. In: The 3rd International Conference on Water Resources and Arid Environments and the 1st Arab Water Forum.

Gad, M. ; K. Dahab and H. Ibrahim (2016): Impact of iron concentration as a result of groundwater exploitation on the Nubian sandstone aquifer in El Kharga Oasis, western desert, Egypt, NRIAG, 5(1): 216-237.

Gameh, M.A. ; N.M. Roshdy ; M.A. Eissa and M.M. Ahmed (2017): Effect of cultivation on the soil properties of El-Kharga farm, New Valley, Egypt. In The 12 th International Conference of ESSS Development of Water and Soil Resources: Challenges and Solutions (pp. 7-9).

Ghallab, A. ; E.M. Khalifa ; S.H.A. El-Aziz and S.A.H. Selmy (2005): Land Capability and Classification of Some Shale-derived Soils in the New Valley, Egypt. Assiut Journal of Agricultural Sciences, 36(4): 45.

Goyer, R.A. (1997): Toxic and essential metal interactions. Annual Review of Nutrition, 17(1): 37-50.

Ismael, H. ; M. Abdel-Motamed and W. Abbas (2020): Environmental and Climatic Hazards and Their Impacts on the Cultural Heritage of El-kharga Oasis, Western Desert, Egypt. Egyptian Journal of Archaeological \& Restoration Studies, 10(2): 135-152.

Kabata-Pendias, A. and H. Pendias (2001): Trace elements in soils and plants. 3rd edition. CRC Press, Boca Raton, Florida, 413 pp 
Karlen, D.L. and D.E. Stott (1994): A framework for evaluating physical and chemical indicators of soil quality. Defining soil quality for a sustainable environment, 35: 53-72.

Kawy, W.A. and I.H. Abou El-Magd (2013): Assessing crop water requirements on the bases of land suitability of the soils South El Farafra Oasis, Western Desert, Egypt. Arabian Journal of Geosciences, 6(7): 2313-2328.

Khan, A. ; S. Khan ; M.A. Khan ; Z. Qaar and M. Waqas (2015):The up take and bioaccumulation of heavy metals by food plants. Environmental Science and pollution Research, 22: 13772 13799.

Ma, L. ; K.M. Qi ; C. Komar ; W. Zhang ; Y. Cai and E.D. Kennelley (2001): A fern that hyper accumulators arsenic. Nture, 409: 579 -585 .

Ma, Q.Y. ; S.J. Traina ; T.J. Logan and J.A. Ryan (1994): Effects of aqueous $\mathrm{Al}, \mathrm{Cd}, \mathrm{Cu}, \mathrm{Fe}(\mathrm{II}), \mathrm{Ni}$, and $\mathrm{Zn}$ on $\mathrm{Pb}$ immobilization by hydroxyapatite. Environmental science \& technology, 28(7): 1219-1228.

Ministry of Public Works and Water Resources (1998): Hydrogeology of deep aquifers in the Western Desert and Sinai; Water Policy Reform Program, International Resources Group Winrock International, Nile Consultants, Report No. 10

Nicholson, N. (1984): A theory of work role transitions. Administrative science quarterly, 172-191.

Okoronkwo, N. E. ; J. C. Igwe and E. C. Onwuchekwa (2005): Risk and health implications of polluted soils for crop production. African Journal of Biotechnology, 4(13): 1525-1529.

Parks, S.L. (2016): Remote Sensing Analysis and Implications for Groundwater Resources in the Kharga Basin, Egypt (Doctoral dissertation).

Salman, A.B. ; F.M. Howari ; M.M. El-Sankary ; A.M. Wali and M.M. Saleh (2010) Environmental impact and natural hazards on Kharga Oasis monumental sites, Western Desert of Egypt. J. Afr. Earth Sci., 58: 341-353.

Sayed, A.S.A. (2013): Evaluation of the land resources for agricultural development-case study: El-Hammam canal and its extension, NW Coast of Egypt (Doctoral dissertation, Staats-und Universitätsbibliothek Hamburg Carl von Ossietzky).

Schoeneberger, P.J. ; D.A. Wysocki and E.C. Benham (2012): Field book for describing and sampling soils. Government Printing Office.

Schoeneberger, P.J. ; D.A. Wysocki and E.C. Benham (2011): Field book for describing and sampling soils, Version 3.0. Natural 
Resources Conservation Service, National Soil Survey Center,Lincoln, NE.

Schoeneberger, P.J. ; D.A. Wysocki ; E.C. Benham and W.D., Broderson (2002): Field Book for Describing and Sampling Soils, Version 2.0. Agriculture. Natural Resources Conservation Service, USDA, National Soil Survey Center.

Soliman, M.M. (2020): "Land and Water Resources Assessment for Sustainable Agricultural Development in El-kharga Oases by Using Remote Sensing and Geographic Information System." Menoufia Journal of Soil Science., 5(2): 55-83.

Sys, C. and W. Verheye (1978): An attempt to the evaluation of physical land characteristics for irrigation according to the FAO framework for land evaluation. Chent: 78707258-78707258.

Tezcan, A. ; K. Büyüktaş and Ş.T.A. Aslan (2020): A multi-criteria model for land valuation in the land consolidation. Land Use Policy, 95.

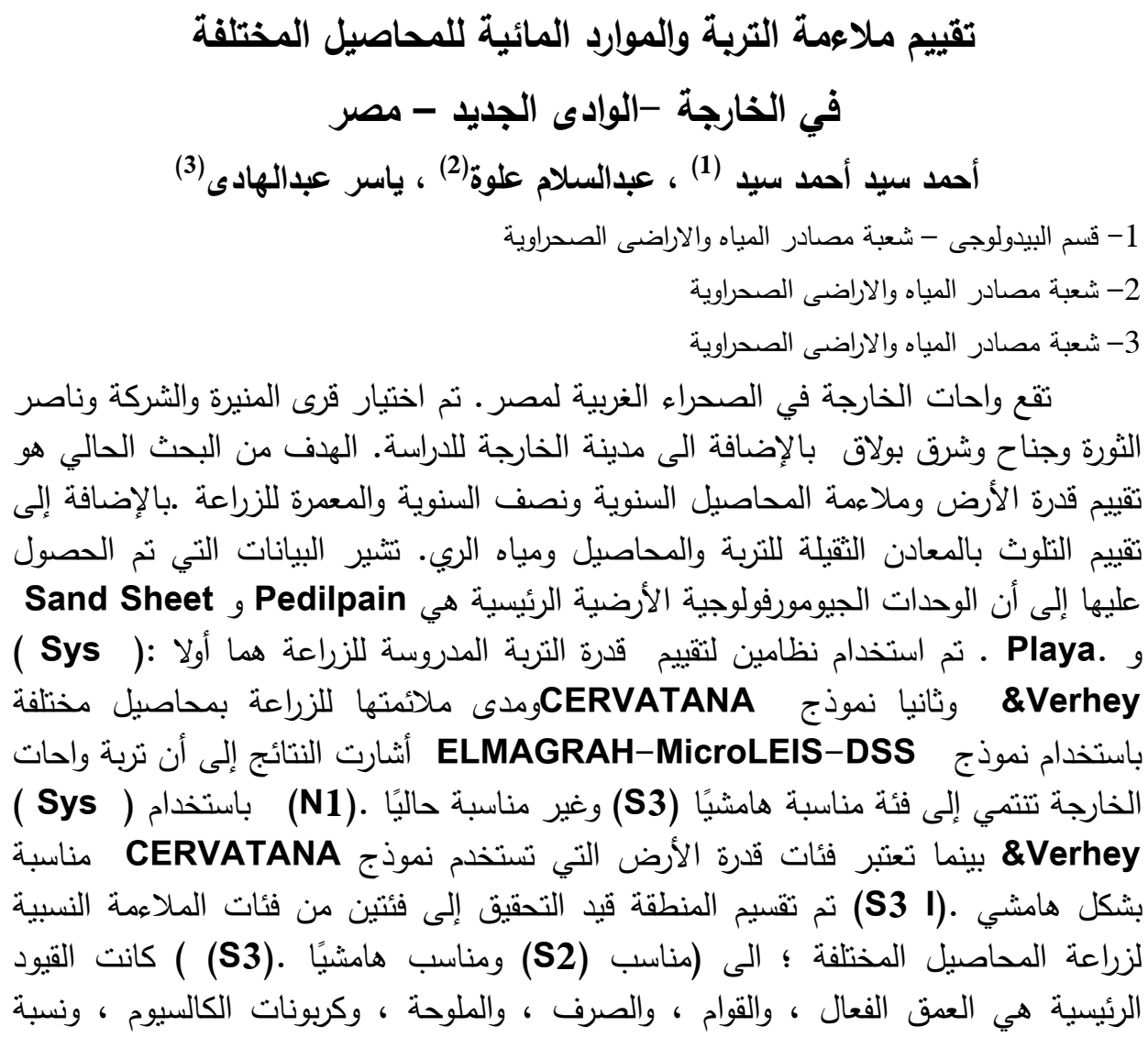


الصوديوم المنبادل. سيؤدي تصحيح هذه العوامل إلى تحسين قدرة الأرض ومدى ملاءمتها

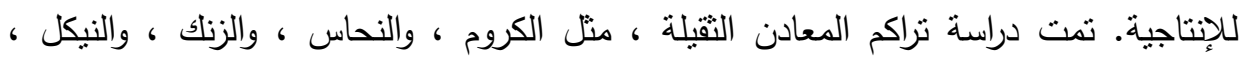

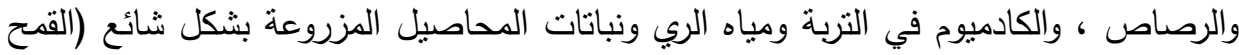

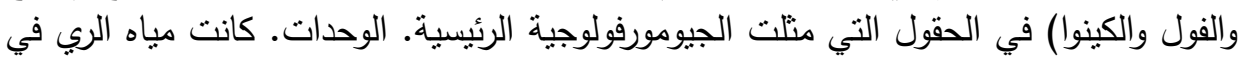

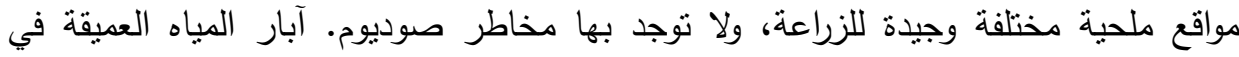

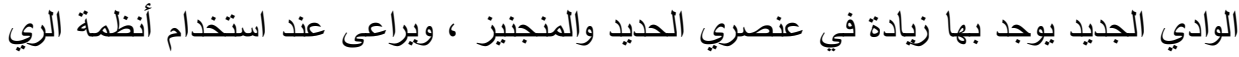

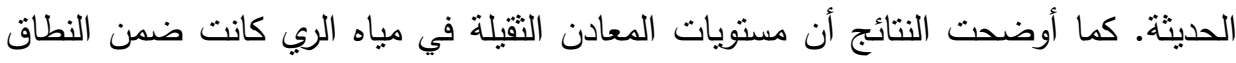

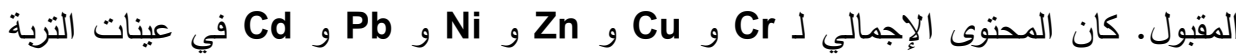

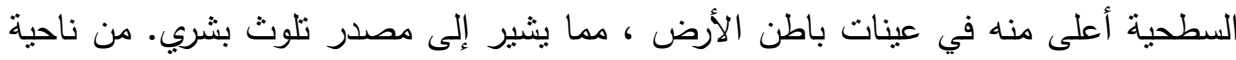

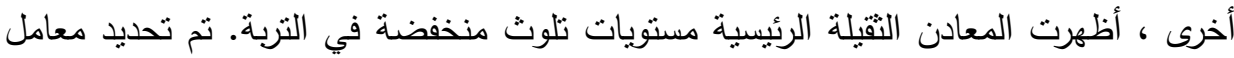

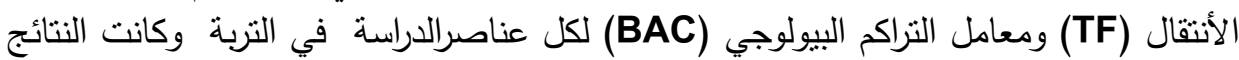

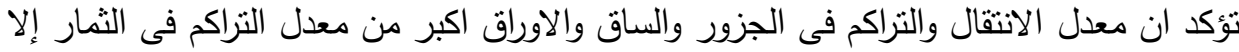

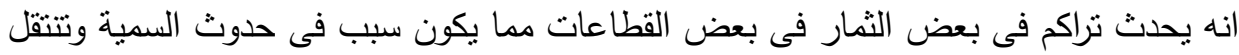

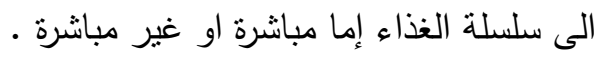

